\title{
Stability assessment of sandstones from the St. Servatius Church in Quedlinburg (UNESCO's World Heritage Site, Germany)
}

\author{
S. Siegesmund • C.-H. Friedel $\cdot$ J. Vogel • \\ S. Mosch • D. Naumann • A. Peter • \\ H. Giesen
}

Received: 8 December 2009/Accepted: 24 August 2010/Published online: 2 October 2010

(C) The Author(s) 2010. This article is published with open access at Springerlink.com

\begin{abstract}
The St. Servatius Church in Quedlinburg (UNESCO's World Heritage Site, Germany) is characterised by long-standing stability problems and structural damages, which have been known over the last several centuries. The monotonous Cretaceous sandstone with its poor lithification is considered to be the main factor. The sandstone is characterised by a high porosity of around 30 Vol.\% (max. ca. 35 Vol.\%) and a corresponding high $w$ value. The porosity and the degree of cementation are responsible for the very low compressive strength of around $8 \mathrm{MPa}$ at maximum, whereas under moisture these values are significantly reduced up to $40 \%$. The freezethaw tests indicate a very poor resistance to frost weathering, which may explain the near-surface softening of the sandstone. Direct shear experiments with an approximate $60^{\circ}$ angle of friction on the sandstone clearly demonstrate
\end{abstract}

S. Siegesmund $(\bowtie) \cdot$ S. Mosch

GZG-Strukturgeologie und Geodynamik Universität Göttingen,

Goldschmidtstr. 3, 37077 Göttingen, Germany

e-mail: ssieges@gwdg.de

C.-H. Friedel

Landesamt für Geologie und Bergwesen Sachsen-Anhalt

(LAGB), Postfach 156, 06035 Halle/Saale, Germany

J. Vogel $\cdot$ H. Giesen

HAWK-Fachhochschule Hildesheim,

Labor Für Bodenmechanik, Hohnsen 2,

31134 Hildesheim, Germany

D. Naumann

Institut für Gebirgsmechanik $\mathrm{GmbH}$,

Friederikenstraße 60, 04279 Leipzig, Germany

A. Peter

Ing.-Büro f. Geotechnik Andreas Peter,

Goezestraße 22, 06484 Quedlinburg, Germany the safety margins. Initial geotechnical modelling does not favour the hypothesis that a landslide of the hill parallel to the southward dipping bedding planes (i.e. shear failure along weak zones) can occur. A prominent clay layer (also with a southward dip) below the entire castle hill is monitored to determine the possible amount of movement with respect to the geological discontinuities (e.g. joints, fractures). At present, a combination of foundation problems are being considered for the stability situation at the church. These include construction deficiencies due to deformation or softening of the foundation of the forerunner churches and missing or faulty connections from building additions. Geological factors responsible for the stability problems include the softening of the sandstone by the influence of weathering and penetrating water as well as the presence of possible shear planes and joints.

Keywords Cretaceous sandstone - Lithology · Diagenetic processes - Weathering - Petrophysical properties $\cdot$ Stability assessment

\section{Introduction}

In the UNESCO world heritage site of Quedlinburg, one of the most famous historical buildings is the collegiate church of St. Servatius, which is a masterpiece of Romanesque architecture. This church and the castle of Renaissance style create the scenic backdrop of Quedlinburg. They are located on the castle hill (Schlossberg), which rises around $25 \mathrm{~m}$ above street level in the old quarter of the town (Fig. 1a).

Over the centuries the stability of the buildings on top of the castle hill has persistently caused problems, especially those related to the Romanic collegiate church (e.g. 

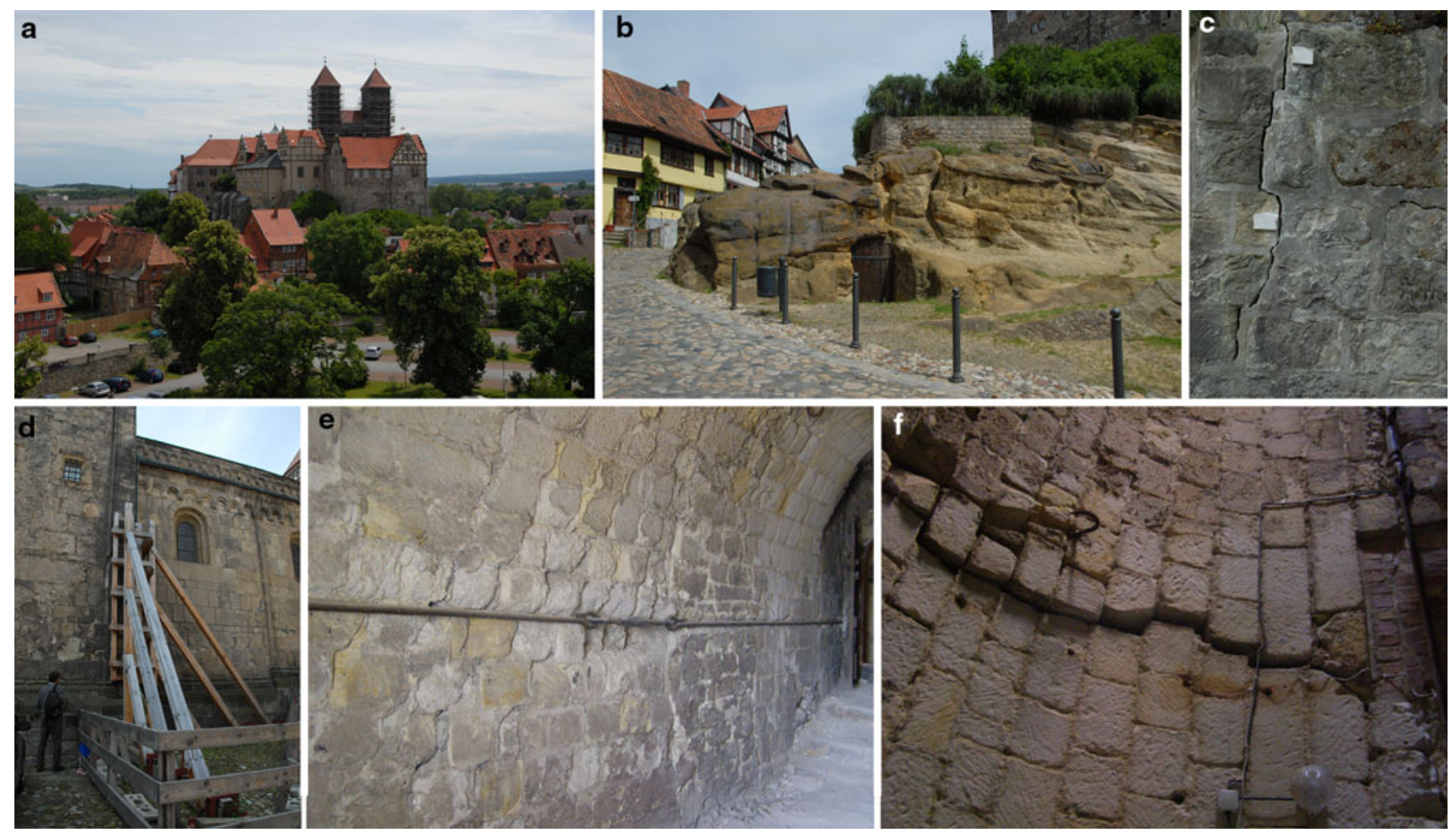

Fig. 1 a View towards the Renaissance-style castle (left) and the Romanic collegiate church of St. Servatius located on the top of the castle hill (Schlossberg) in the old part of Quedlinburg. b Slightly cemented early Cretaceous quartz sandstones of the castle hill, which are protected from erosion by a thin conglomerate layer. It contains

Prescher 1955). Primarily, these problems may be traced to the bedrock, which consists of Lower Cretaceous sandstone. In recent years, efforts have been made to safeguard the buildings, whereby the substratum of the St. Servatius church and castle have been investigated using an interdisciplinary multi-methods approach consisting of:

- Direct probing of the rock mass by drilling-delivering representative drill cores for lithological, petrophysical and geotechnical laboratory investigations (used for estimating representative geotechnical parameters for the modelling)

- Geophysical surveys with bore hole logging and seismic tomography

- Rock mechanical modelling of the actual geotechnical situation

The investigations were partly initiated by the State Office of Geology and Mining of Saxony-Anhalt (LAGB), who were also directly involved in the investigation and analysis of the seismic tomography (Heckner et al. 2005) and drill hole logging.

Results are presented from the detailed petrographic investigations, which provide the first indications of possible causes for the reduced stability of the sandstone. This oxidised ironstones and well-rounded quartz pebbles. The strata of the castle hill dip $25^{\circ}-30^{\circ}$ towards the southwest. c-f Structural damages such as crack formation, structural disintegration and support structures made from wood and iron chains to safeguard against the predominant damages

is due to the strength and weathering behaviour of the rock that was determined by the measured petrophysical and geotechnical properties. In addition, the latter geotechnical variables were used for the geotechnical modelling, without which a reliable evaluation of the actual geotechnical situation is not possible. Finally, the geotechnical stability of the bedrock is assessed with regard to the influence of the collegiate church on the substratum and the resulting stress. A short review of the construction history of the building, structural damages and the general geological framework is described as a prerequisite for understanding the present-day situation.

\section{Construction history}

The castle hill is located in the western part of the town of Quedlinburg. The top of the castle hill forms an ovalshaped plateau around $20-25 \mathrm{~m}$ above the surrounding area (Fig. 1a, b). Throughout the centuries, the plateau was extended on almost all of its sides by earlier constructions and filled ground.

The earliest settlement of the castle is documented by the discovery of flint tools. The first wall enclosure 
originates from the Bronze Age. In the central nave of the church, cellar vaults from the Iron Age can be found, a rock-earthwork structure from around $500 \mathrm{CE}$, and post holes have been verified suggesting the construction of a wood hall. The latter is dated to the eight and ninth century.

According to Wäscher (1959) and Voigtländer (1989), the present-day collegiate church and fourth construction precedes three earlier church buildings all constructed at the same location. The first church was built in the ninth century. It consisted of a three-naved basilica where the present-day eastern half of the crypt is located. The wayside chapel south of the present transept is probably even older. After the year 936, the second church was constructed with a size equivalent to the present-day crypt. The third church construction took place in two stages, initially as an extension on the existing church (consecration in 997) and later through a new construction in the area of the second church (consecration in 1021). The size of the third church building correlates to that of the present-day collegiate church. In the course of this construction the wayside chapel was overbuilt and the south side extended by the present-day counter arches. After the complete destruction of the church by fire in the year 1070, a new construction period began until 1129, which built the fourth church to its present-day size. This was essentially built on the foundation of the third church. Later the counter arches were overbuilt with the buildings of the provost residence. The residence was destroyed by a fire in 1846 . At the end of the nineteenth century, a comprehensive restoration of the buildings on the castle hill was undertaken, whereby the south tower was also rebuilt. After about 30 years the south tower needed additional support through a buttress that is connected by an iron jointer to the north tower.

\section{Structural damages}

The buildings on the castle hill of Quedlinburg have shown damages for many centuries. The predominant damages visible are partial collapses as well as misalignments on the surrounding ring wall which encloses the hill. Crack formation is observable within the collegiate church, the towers and in the counter arches (Fig. 1c-f). These damages have essentially been attributed to the stability of the supporting bedrock, which is made up of a weakly cemented shallow marine sandstone with a dip of about $25^{\circ}-30^{\circ}$ to the southwest. More recently, building operations have shown that the damages on the ring wall and the counter arches are the result of structural deficiencies and a temporal decomposition of the material strength. The high ring walls (ca. $17 \mathrm{~m}$ high) are constructed as heavy walls and consist mostly of sandstone. The lower part of the wall is mostly attached to the in situ bedrock. The upper part (ca. $7 \mathrm{~m}$ ) supports the raised terraces and the baroque garden. The predominant damages occur as a result of insufficient structural integrity (tilting) as well as absent drainage and the associated decrease in the strength of the wall structure.

The causes for the damages in the collegiate church are still not resolved. Even though the bedrock has a low strength, the sandstone forms a sufficient stable foundation for the collegiate church. Crack formations present in the church are only a few millimetre in width and oriented parallel to the long axis, and are clearly not the result of a collapsing substratum (base failure). A slope failure of the hill oriented parallel to the southward dipping rock layers is probably not going to occur. Stronger damages would be expected by a landslide, which would have caused a collapse of the church. Furthermore, previous investigations in the sandstones found no potential slide planes, such as claystone layers (Prescher 1955).

\section{Geological framework}

The castle hill is situated at the southwestern flank of the Quedlinburg anticline close to the city centre, where the anticline is crossed by the Bode River. The Quedlinburg anticline is a ca. 30-km long NW-SE striking fault-related and salt-cored anticlinal structure, subdividing the eastern part of the Subhercynian Cretaceous Basin (SCB) in the Blankenburg and the Halberstadt synclines, respectively (Fig. 2). From the Hauterivian up to the Campanian, the SCB comprises a nearly complete succession of mainly shallow marine sediments (marls, limestones and sandstones), which is interrupted by periods of synsedimentary erosion. Lower Cretaceous sediments are only locally preserved in the eastern SCB, particularly in a graben-like position at the Quedlinburg anticline (Fig. 2). In the Quedlinburg anticline, the Lower Cretaceous Hauterivian to Barremian sediments are mainly quartz arenites that reach a thickness of up to $400 \mathrm{~m}$. In contrast, Upper Cretaceous sediments are widely distributed and attain a thickness of more than 2,000 m mainly as the result of a tectonically induced subsidence, which is controlled by the uplift of the Variscan basement unit of the Harz block (Voigt et al. 2004, 2006; von Eynatten et al. 2008).

The Lower Cretaceous, ca. $125 \mathrm{Ma}$ old (Barremian) sediments cropping out on the castle hill consist mainly of monotonous, well sorted, fine- to medium-grained shallow marine quartz arenitic sandstones (Neokom-Sandstones) intercalated with some claystone layers and conglomerate beds (Voigt and von Eynatten 2008). The conglomerate beds and parts of the sandstones were more or less infiltrated by iron ore-bearing fluids (limonite), yielding a yellow to red colour of the originally light to greyish coloured rocks. The red and light coloured sandstones and 
Fig. 2 Geological map of the Subhercynian Cretaceous Basin (without Cenozoic sediments) The Quedlinburg anticline subdivides the eastern part of the basin. Note that beds of lower Cretaceous age are preferably exposed along this anticline. The star marks the position of the castle hill at the western part of Quedlinburg
Fig. 3 a 3D view of the imposing structures on the castle hill (from Peter 2005). b Cross section along $\mathrm{AA}^{\prime}$ that shows the upper limit of Lower Cretaceous bedrock and the general SW dip. The dip of sedimentary layering is also marked by a horizon with claystone layers encountered in boreholes BK 1, 3, and 7
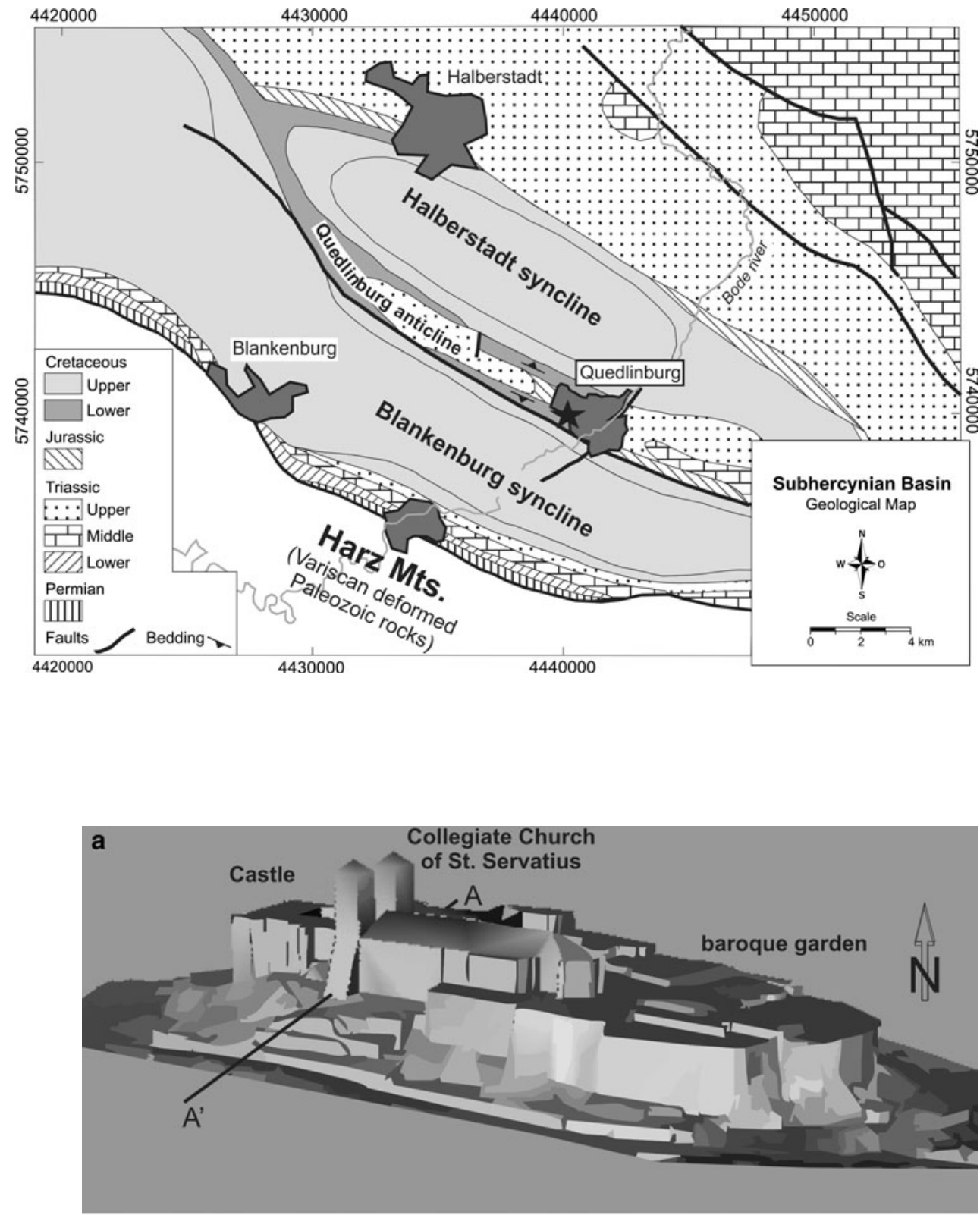

b

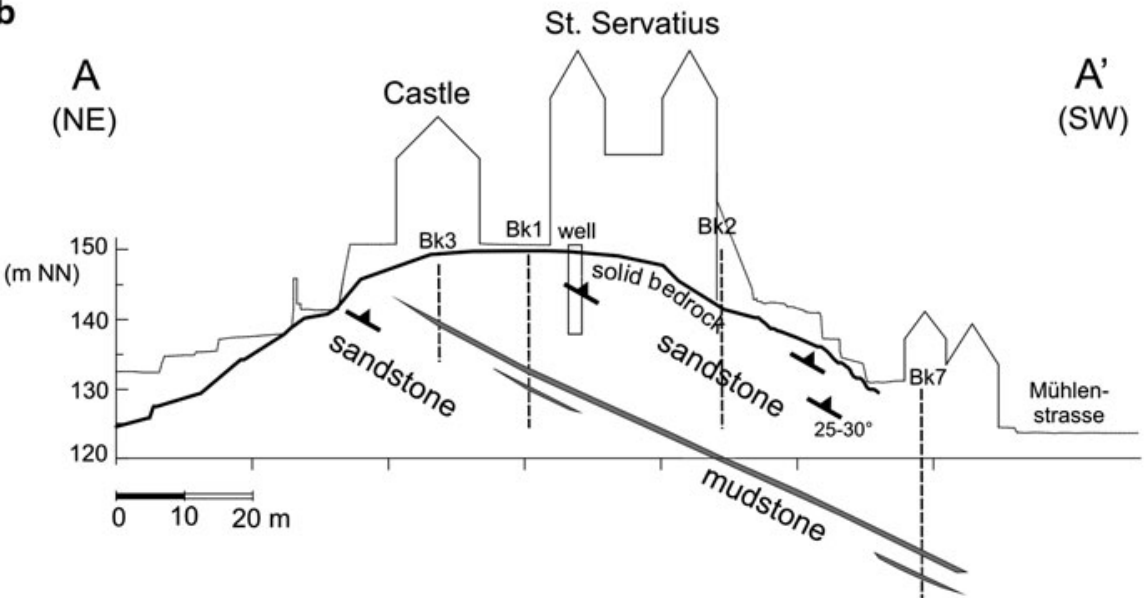


conglomerates are well exposed at the western flank of the castle hill (Fig. 1b). About 16-m below the top of the hill and recovered only from drill holes, an up to $2.5-\mathrm{m}$ thick horizon of dark grey claystone layers intercalated with limonitic sandstone occurs parallel to the sandstone bedding (Fig. 3). Similar to their position in the southwestern flank of the Quedlinburg anticline, the strata of the castle hill dips $25^{\circ}-30^{\circ}$ towards the southwest.

\section{Petrography and diagenetic pattern}

Tröger (1955) was the first to systematically investigate the sandstone petrography (porosity and grain size) from the castle hill. Optical and cathodoluminescence microscopy were used to characterise the diagenetic rock features of cementation and porosity in more detail. For petrographic purposes about 20 samples have been selected from two 25-m deep boreholes, which were drilled on top of the castle hill in 2007 (Bk1 and Bk2, cf. Fig. 3b). Most of the samples are fine- to medium-grained friable and porous sandstones that contain nearly pure quartz grains (ca. 99.9\% quartz), typical for the Lower Cretaceous quartz-arenites (Tröger 1955; von Eynatten et al. 2008). The grains are sub-angular to sub-rounded and consist mostly of clear monocrystalline quartz (Fig. 4). Under the cathodoluminescence (CL) microscope, several quartz grains display blue and red CL colours, while most of the grains only show a low luminescence (Fig. 4b). Blue and red CL colours may indicate a magmatic and/or metamorphic origin. However, CL colour alone may not to be a reliable indicator for identifying the origin (and provenance) of detrital quartz grains (Boggs et al. 2002). In conglomerates and medium- or coarsergrained sandstones, other components are visible, e.g. limonitic grains and microcrystalline quartz aggregates forming sandstone pebbles (Fig. 5).

Most of the quartzose sandstones are only weakly cemented with quartz, except for limonite-cemented or claybearing layers. The friable, weakly lithified sandstones display a total porosity of about $30 \mathrm{Vol} \%$ (see "Petrophysical and geotechnical properties"). The initial cementation consists of dull luminescent microcrystalline quartz developed at point contacts between grains (Fig. 4b). A somewhat advanced stage of quartz cementation is represented by fine fringes of quartz crystals radially oriented on the grains (radial quartz cement, Fig. 4c). Some dull luminescent syntaxial quartz overgrowths on detrital quartz grains can also occur. The contacts between the quartz grains are straight to curved, but not sutured. Some grains display stronger penetrating concave-convex contacts which indicate grain dissolution (Fig. 4b). The latter feature clearly indicates the initiation of pressure solution and may

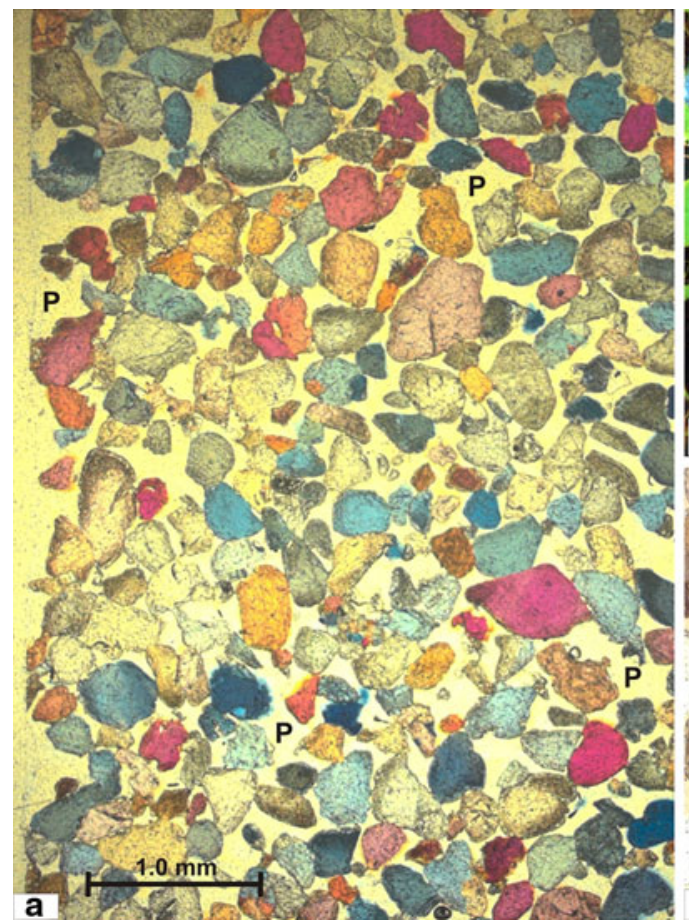

Fig. 4 a Pore space $(P)$, grain shape and weak cementation in common quartzose sandstones. b Cathodoluminescence image of medium-grained sandstone with initial (dull luminescent) microcrystalline quartz cementation (white arrows) linking grains by cement-

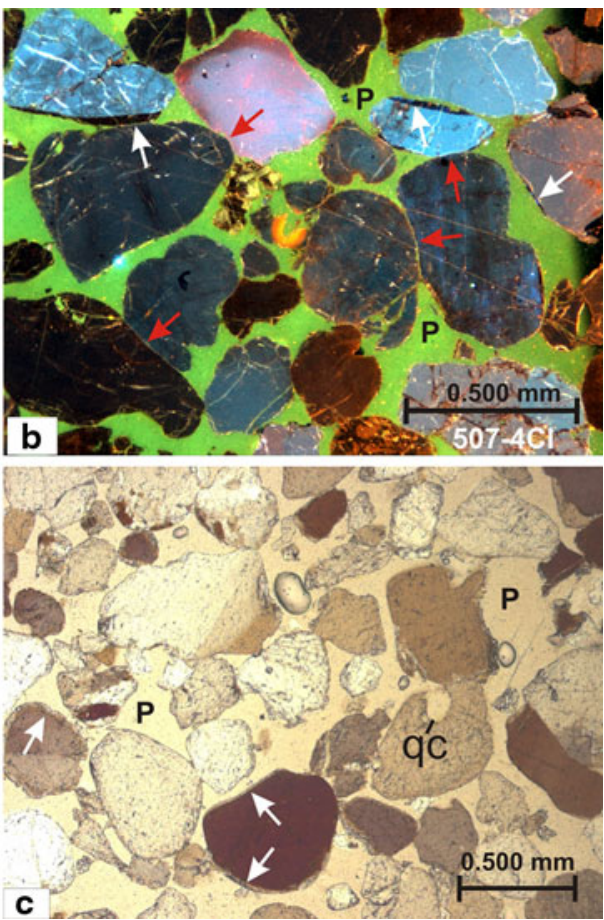

bridges. The red arrows indicate stronger penetrated grain contacts (convex-concave grain contact, see text). c Radially oriented quartz crystals periodically occur, forming small cement fringes. Note also the partly dissolved (embayed) quartz grain $(q c)$ at the centre of $\mathbf{c}$ 
Fig. 5 Strong limonitecemented sandstones $(\mathbf{a}, \mathbf{b})$, and limonitic conglomerates (c, d). Note the vuggy (secondary) porosity in the sandstones. The secondary porosity arises from matrix and framework grain dissolution. The latter is shown by selective dissolution of limonitic grains in the conglomerate beds (c, d, white arrows). d Limonite-filled fractures (black arrows) suggest that limonite cementation occurred relatively late in the course of diagenesis. Note also the sandstone pebble in $\mathbf{c}$ (black arrow). $P$ pore space
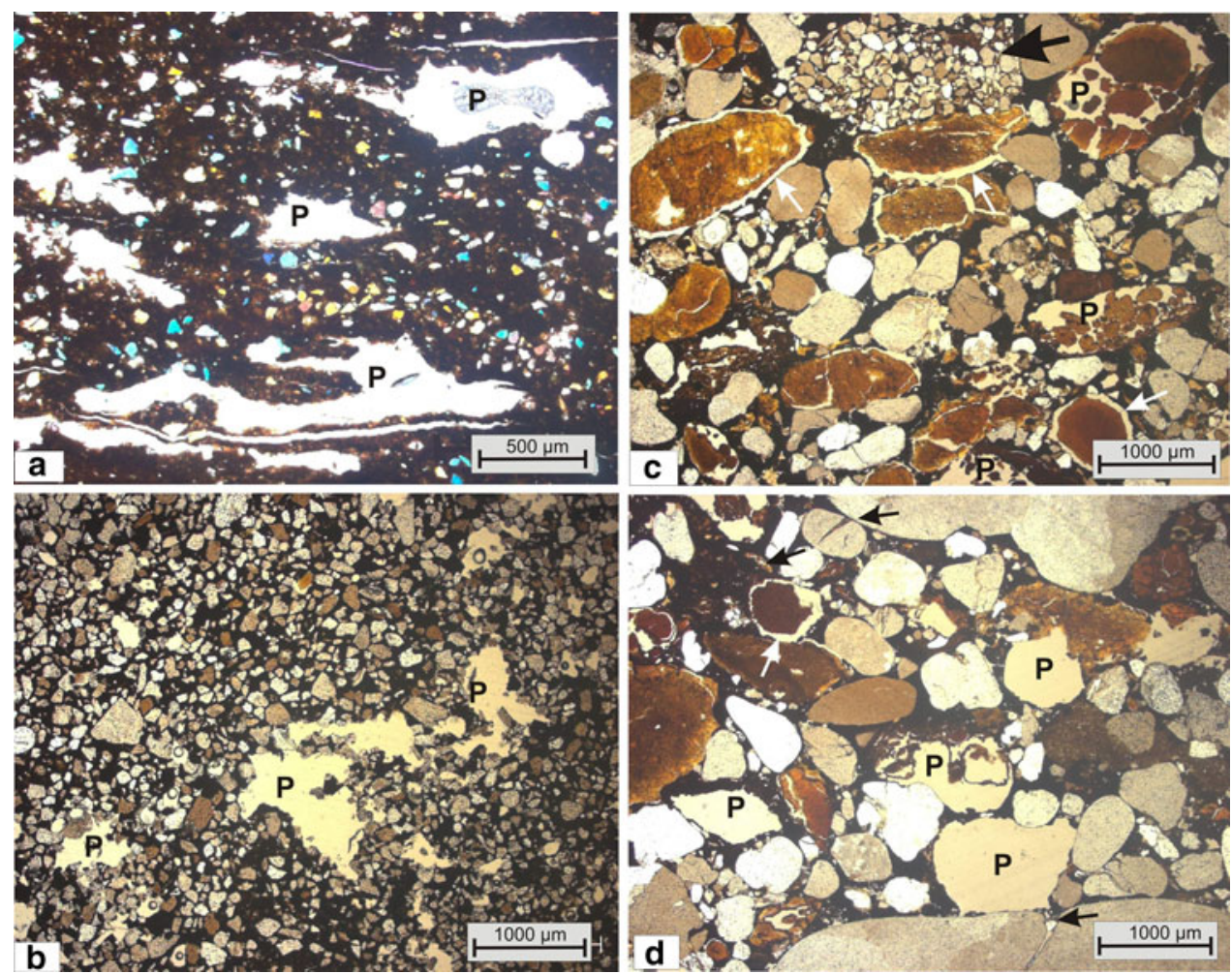

suggest that pressure solution was the main source for quartz cementation. However, pressure solution did not exceed an initial stage, because of the lack of sutured grain contacts, and the weak quartz cementation, which commonly did not occlude more than $10 \%$ of the original pore space.

Some samples are strongly cemented by limonitic iron ore (Fig. 5). In the limonite-cemented sandstone, dull luminescent quartz cement also occurs, which predates the limonitic infill. Furthermore, limonite commonly transects the bedding, and hence, the infilling of void spaces by limonite occurred relatively late, probably during or after mechanical compaction (Fig. 5d). Limonite effectively reduced the porosity until the primary (intergranular) pore space was completely filled (Figs. 5, 6). However, limonite-cemented sandstones commonly display a secondary porosity. Secondary porosity is characterised by oversized, bedding parallel and irregularly formed dissolution vugs (Fig. 5a, b). As shown in Fig. 5c and d, dissolution preferably affected the limonitic components, which are partly or totally removed by selective dissolution leaving grainshaped pores (moldic porosity).

Secondary pore spaces were also observed in the claybearing sandstones. Furthermore, oversized pore spaces and corroded (embayed) quartz grains in weakly quartzcemented sandstones indicate that secondary porosity due to dissolution may occur in all lithologies. In the wellcemented rocks secondary porosity can even reach $20 \%$, but in the weakly quartz-cemented sandstones their amount is difficult to estimate. The kind and source of the dissolving fluid is still unknown.

The diagenetic processes and evolution of porosity is summarised in Fig. 6. Only two main stages of diagenesis are distinguished, a first stage that comprises mechanical compaction, initial pressure solution and precipitation of dull luminescent quartz cement and a second stage characterised by dissolution. Initial pressure solution producing point and convex-concave grain contacts accompanied with quartz cementation (dull luminescent) appears to be the dominant process for lithification of the sandstones. The supply of silica for quartz cement was limited and only caused a low reduction of the intergranular pore space (not more than $10 \%$, Fig. 6). In several sandstones the remaining pore space was partly or totally cemented with limonite. Subsequently, matrix and framework grain dissolution affected all the rock types and probably contributes to the friable framework in quartz-cemented sandstones. Nevertheless, the small amount of cementation is the main reason that the present average porosity still remains high in most of the sandstones (mean $30 \mathrm{Vol} \%$ ). Furthermore, the diagenetic pattern indicates that the shallow marine sandstones were never deeply buried, probably not more than about $2,500 \mathrm{~m}$ until the Late Cretaceous or younger, when the Subhercynian Cretaceous Basin reached its maximum depth (Voigt et al. 2004).

Preliminary mapping about 16-m below the edge of the plateau has revealed a clay layer that has a thickness of 
Fig. 6 Diagenetic processes and pore space evolution. Note that at the final stage of diagenesis the porosity of most of the sandstones is not significantly reduced, resulting from weak quartz cementation and some dissolution. $L P$ limonitic pebbles. See text for further explanation

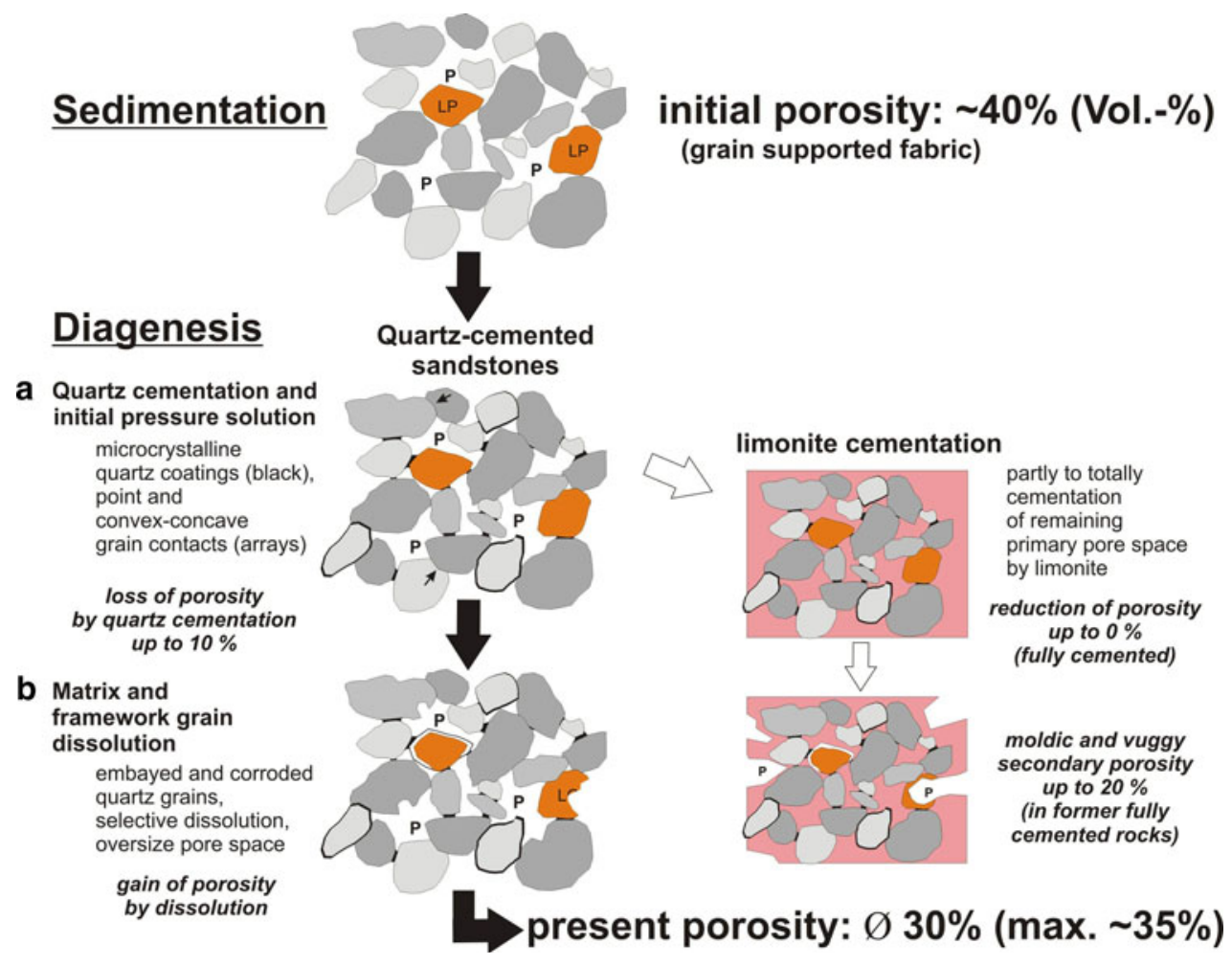

about $2.5 \mathrm{~m}$. This layer occurs throughout the entire castle hill, and is parallel to the sandstone bedding with a dip ranging $25^{\circ}-30^{\circ}$ to the $\mathrm{SW}$. The determination of the liquid- and plastic limit for the clay sample BK 1-11 resulted in a liquid limit of $29 \%$, a plastic limit of $17 \%$ and a plasticity index of about $12 \%$. The sample is slightly plastic clay, and according to the DIN 18196 it belongs to the soil group "TL".

\section{Petrophysical and geotechnical properties}

Grain size distribution

Different physical and mechanical properties of sandstone are controlled to a great extent by the grain size distribution. To describe the differences between the varieties of the sandstone that have a generally similar appearance, sieve analyses were carried out following the DIN 18123 (1996). Samples were crushed carefully by hand, so as not to destroy the internal grain structure.

Two groups of sandstone varieties can be distinguished (compare with Tröger 1955): (1) fine-grained sandstones where 60 to $90 \mathrm{wt} \%$ of the rock show particle size fractions ranging $0.06-0.2 \mathrm{~mm}$, and (2) medium-grained sandstones with more than 70-80 wt \% having particle size fractions ranging $0.2-0.6 \mathrm{~mm}$ (Fig. 7). Grain sizes lower than $0.06 \mathrm{~mm}$ could not be detected in any sample. Since crushing was done by hand, some particles belonging to the silt fraction can exist in accumulated form. The castle hill is made up of more or less well-sorted sandstone commonly without particles in the fine silt or even clay fraction. Apart from sample BK1-11 (claystone), only such samples, which do not contain clay or more than $10 \%$ limonite cement were generally used for petrophysical investigations.

Density and pore space properties

The bulk density and the effective porosity of the sandstones were investigated by buoyancy weighing according to the EN 1936 method. To calculate the rock parameters of the dry mass, the water-saturated mass and the mass immersed in water were determined. Cylindrical samples were used where the diameter and length each measure $40 \mathrm{~mm}$.

The averaged bulk density of the fine-grained samples BK 1-2, 1-15, 1-16, 1-12 and 1-13 range from 1.74 to $1.85 \mathrm{~g} / \mathrm{cm}^{3}$ with corresponding values for the effective porosity of 34.2 and 29.9 Vol.\%, respectively (Fig. 8). Contrary to expectations that increasing grain sizes lead to higher porosity (e.g. Mosch 2008), the medium-grained samples BK 1-4, 1-3, 1-10, 1-5, 1-6 and 1-9 show somewhat lesser values between 26.1 and 33.7 Vol.\% (mean 29.0 Vol.\%). The averaged bulk density for these samples varies from 1.73 to $1.95 \mathrm{~g} / \mathrm{cm}^{3}$ (mean $1.87 \mathrm{~g} / \mathrm{cm}^{3}$, Fig. 9). 
Fig. 7 Characterisation of grain size distribution in the castle hill sandstone varieties

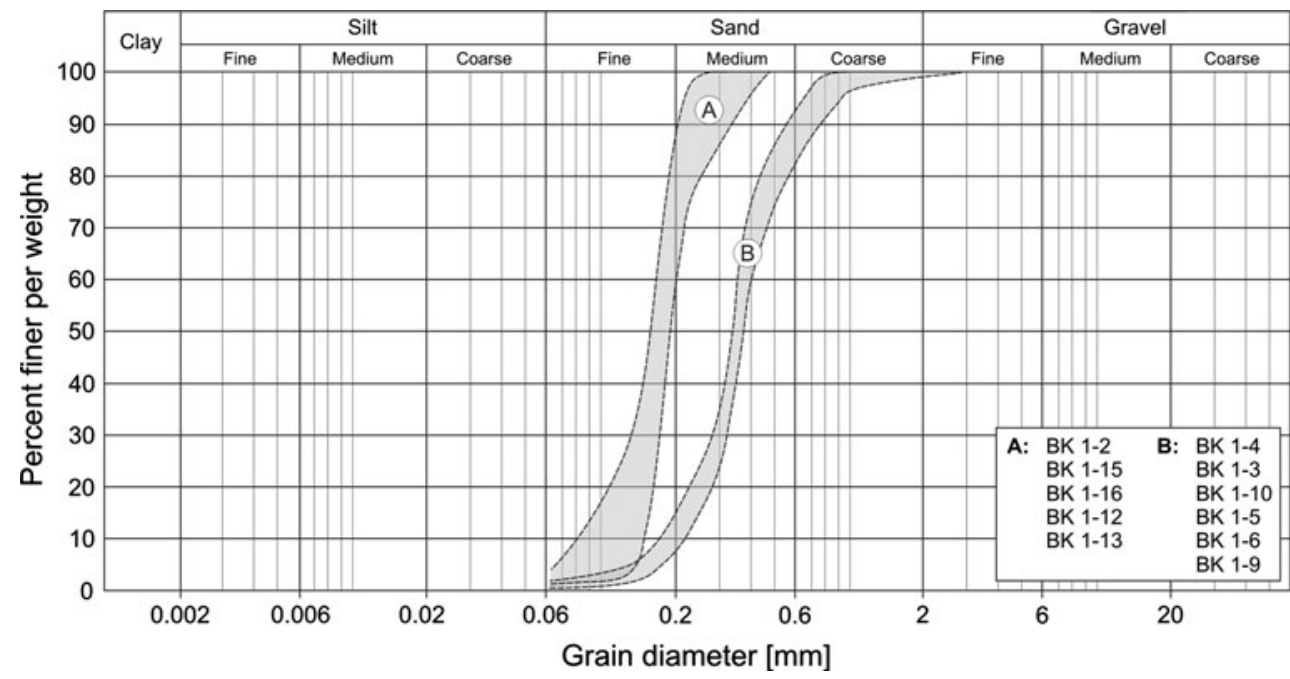

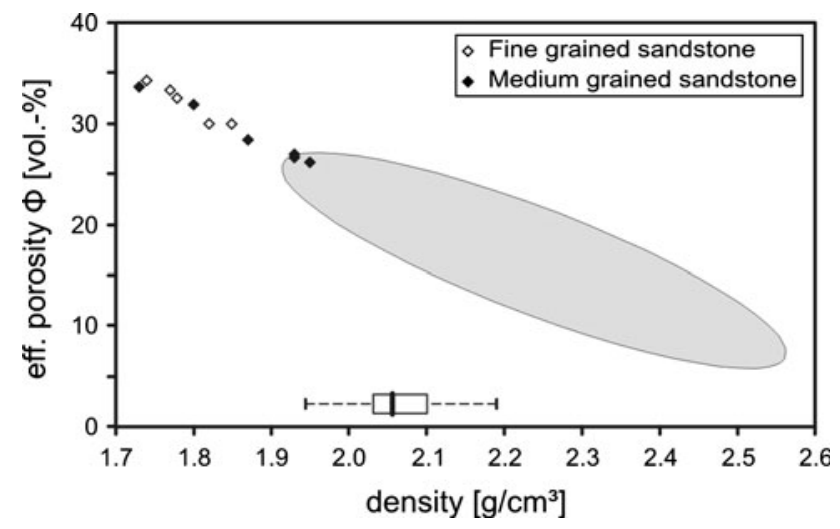

Fig. 9 Scatter plot of density and effective porosity (ellipsoid confidence region describing $80 \%$ of the expected population based on data of 288 sandstones; boxplot typical range of values for sandstones with $\Phi \geq 20.5 \mathrm{Vol} \%$ based on data for 73 varieties used as dimension stone; dataset from Mosch 2008): the comparison to the data of Mosch (2008) shows the very weak lithification of the sandstones from the castle hill in Quedlinburg

lower peak corresponding to micropores ranging from 0.0040 to $0.0063 \mu \mathrm{m}$. The highest pore size occurs in sample BK 1-6 $(33.50 \mu \mathrm{m})$. Furthermore, the effective porosity detected by mercury injection porosimetry (17.8 Vol.\%) is much lower than the value detected by buoyancy weighing $(28.4 \mathrm{Vol} . \%)$. The difference is probably connected to the existence of larger dissolution pores (cf. "Petrography and diagenetic pattern"), which cannot be identified by means of mercury injection porosimetry.

Capillary water absorption

Moisture content is considered as an important parameter for controlling different processes of weathering. Capillary water absorption tests were carried out following the EN 1925. The increase in weight due to the water absorption was 

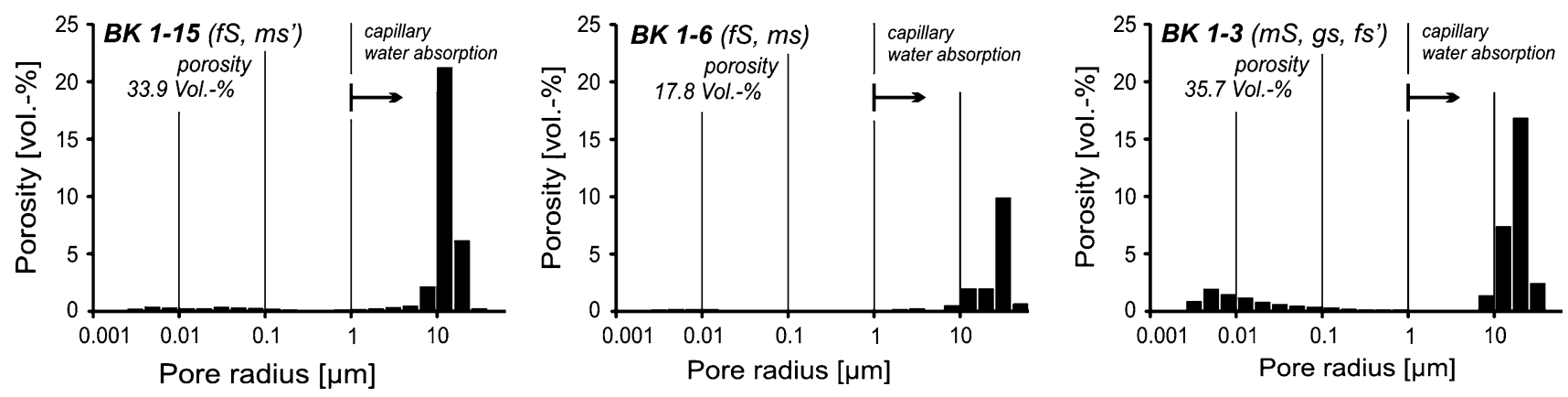

Fig. 10 Pore radii distribution for all investigated sandstone varieties. A clear maximum developed in the range of capillary water absorption. In the case of sample BK 1-3 a weak sub maximum $<0.01 \mu \mathrm{m}$ can be seen

determined directly by means of a digital hanging scale. Measurements were done on cubic specimens with edge lengths of about $65 \mathrm{~mm}$ and were dipped into around $0.5 \mathrm{~mm}$ of water. To determine the directional dependency, the $w$-value was calculated from the capillary water absorption data from two directions in each sample (Fig. 11). In general, the high effective porosities of the rocks lead to a high $w$-value between 23.16 and $31.63 \mathrm{~kg} / \mathrm{m}^{2} \sqrt{ } \mathrm{h}$, whereas no unambiguous anisotropy due to the bedding could be determined. Thus, the sandstone of the castle hill becomes permeated very quickly under atmospheric conditions.

\section{Thermal endurance and CIF-testing}

Frost weathering is a major process in the deterioration of rocks, especially when they are used as dimension stones (Ruedrich and Siegesmund 2006). Alternating freeze-thaw cycles may result in a breakup of the rock mass, if for example the pressure of ice crystallisation exceeds the tensile strength of the rock. To investigate the resistibility of the sandstone, CIF tests (Capillary suction, Internal damage and Freeze-thaw tests, e.g. Auberg et al. 1999) were carried out, where the specimens had to pass through 30 temperature cycles between $-20^{\circ} \mathrm{C}$ and $+20^{\circ} \mathrm{C}$. Cubic shaped specimens of $11 \times 7 \mathrm{~cm}$ were used. The longitudinal edge of each specimen was orientated parallel to the drill hole direction. Due to a coating with epoxy resin on the side surfaces, which prevents the breaking of the stone, water absorption can only take place at the undersurface (Fig. 12). To detect a possible disaggregation of the rock, the ultrasonic wave velocity was measured after a number of cycles (e.g. at 2, 6, 18 and 30 cycles).

The results of the freeze-thaw tests show that the sandstone in general, and especially the coarser-grained variety (BK 1-9), does not possess good resistance against frost weathering. Already after 6 loading cycles the loss of weight reached a value of more than $1 \%$ (Fig. 13a). During cycles 7 and 18 the complete collapse of the specimen followed.
Although the loss of weight for sample BK 1-2 was just $2.3 \%$ after 30 loading cycles, the ultrasonic wave velocity $\left(V_{\mathrm{p}}\right)$ describes a clear disaggregation of the specimen (Fig. 13b). In general, $V_{\mathrm{p}}$ is very low with values $<2 \mathrm{~km} / \mathrm{s}$. After the 30th freeze-thaw cycle $V_{\mathrm{p}}$ had decreased even below $1 \mathrm{~km} / \mathrm{s}$. Thus, the mechanical strength of the rock can be assumed to be near zero.

\section{Compressive strength test (uniaxial strength testing)}

Compressive and uniaxial strength tests following the EN 1926 were performed to describe the mechanical strength of the rock, i.e. focusing on the matrix strength. Specimens of $40 \mathrm{~mm}$ in diameter and $40 \mathrm{~mm}$ in height with co-planar end-faces were used, oriented parallel to the drilling axis (Fig. 14a). Sedimentary layering is about $25^{\circ}$ diagonal to the load direction. This corresponds to the real stress situation at depth with regards to the bearing load of the overlying rock mass and building. Compressive strength is sensitive to the water saturation (e.g. Morales Demarco et al. 2007). Therefore, the specimens were dried until weight constancy, which is defined as the dry status of the specimens. To define fully saturated conditions, a second sample set was evacuated and saturated with water.

Due to the weak lithification of the rock, all the samples tested show very low compressive strength in comparison to sandstones in general (Fig. 14b). The samples display brittle failure with a distinct maximum after a few percent of axial strain followed by a weak residual strength plateau. Despite the observed layering no hints of development of discrete shear failure were observed. The highest medium value is between 7.11 and $8.15 \mathrm{MPa}$ for sample BK $1 / 3$. The maximum single value (9.55 MPa) was reached for a specimen from BK 1/12, one of the fine-grained sandstone varieties. In general, the mechanical strength of a rock increases with lower values of porosity (e.g. Mosch 2008). In the case of the castle hill sandstones, a distinct correlation between the grain size distribution of the samples and the mechanical stability, i.e. the resistance to uniaxial 

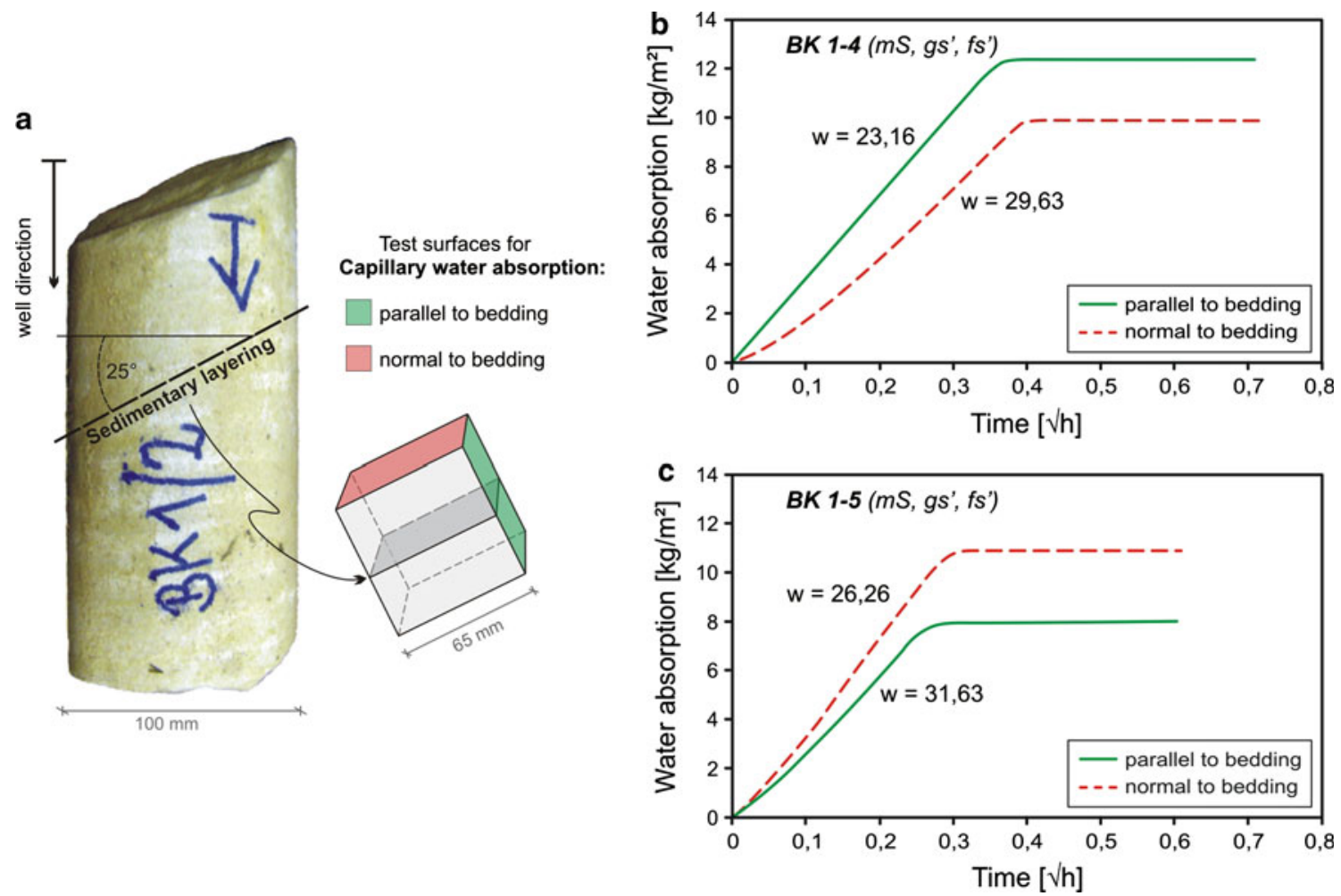

Fig. 11 Capillary water absorption test: a sample preparation to determine directional dependency; water absorption coefficient $w\left[\mathrm{~kg} / \mathrm{cm}^{2} \sqrt{ } \mathrm{h}\right]$ of $\mathbf{b}$ fine-grained and $\mathbf{c}$ coarse-grained sandstone as a function of time (water absorption coefficient $w$ )

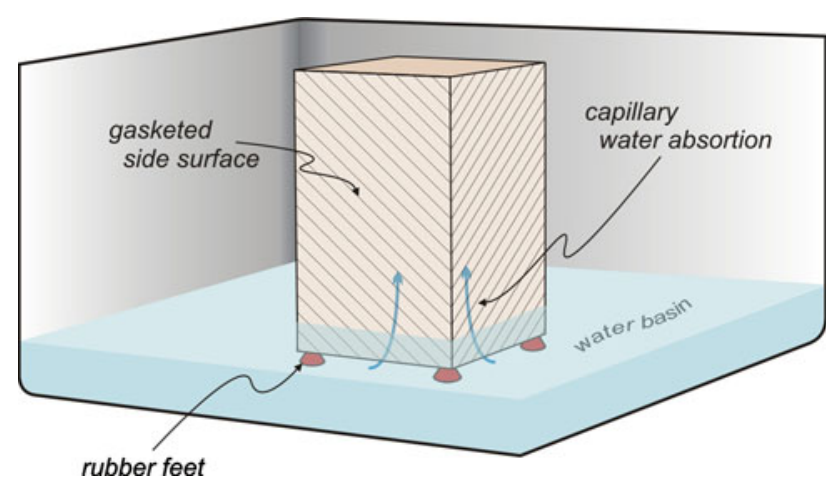

Fig. 12 Experimental setup for the CIF test (Capillary suction, Internal damage and Freeze-thaw test)

compressive load could not be observed. Concerning the loss of mechanical stability due to the water content, it becomes clear that the saturation of the samples can lead to a reduction of the compressive strength of up to almost $40 \%$ (Fig. 15). For sample BK 1/6, a medium-grained variety, the compressive strength is not more than $2.58 \mathrm{MPa}$. In limonite-cemented samples distinctly lower porosities occur, and hence a higher bulk density (and strength) has been established (the uniaxial compressive strength in red-brown (limonitic) sandstone is 10 times higher, Peter 2005).

\section{Bedding plane strength: direct shear experiments}

In addition to rock joints, bedding planes are probably the clearest example of existing interfaces, which may act as a plane of weakness in the strata. The slip criterion for a bedding plane is often expressed as an equation that stipulates the maximum permissible shear stress along the slip surface being analysed. The simplest form, the linear Mohr-Coulomb (MC) criterion is written as

$\tau_{\max }=\mathrm{c}^{\prime}+\sigma_{\mathrm{n}}^{\prime} \tan \Phi^{\prime}$

Here, $\tau_{\max }$ is the maximum shear stress that the plane can sustain before slip; $\mathrm{c}^{\prime}$ is the cohesion of the rock; $\sigma^{\prime}{ }_{n}$ is the normal effective stress across the slip plane; and $\Phi^{\prime}$ the internal friction angle. The material parameters $c^{\prime}$ and $\Phi^{\prime}$ are determined empirically from testing. In this study two different experimental setups were used to determine the discrete shear strength of bedding planes in sandstones dipping $25^{\circ}-30^{\circ}$ in the Quedlinburg castle hill: (1) low loading conditions with $\sigma_{\min }<800 \mathrm{KN} / \mathrm{m}^{2}=0.8 \mathrm{MPa}$, mainly performed on disintegrated samples with various grain sizes, i.e. relevant from the view of soil mechanics; (2) increased load conditions up to $\sigma_{\min }<3 \mathrm{MPa}$, which may be representative for the intact core material.

Altogether 68 experiments were performed in the soil mechanics laboratory. A wide range of lithological and 


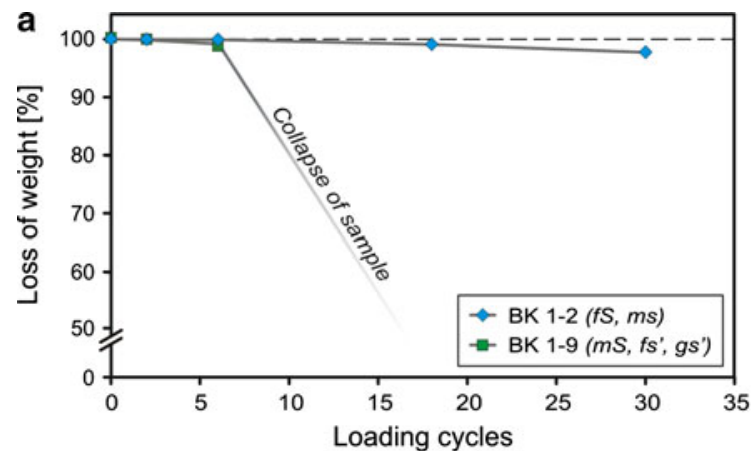

Fig. 13 Results of the freeze-thaw tests $\left(-20^{\circ} \mathrm{C} /+20^{\circ} \mathrm{C}\right)$ between loading cycles 6 and 18. The grain structure of the coarse-grained sample BK 1-9 collapsed completely. Boxplot in b describes the

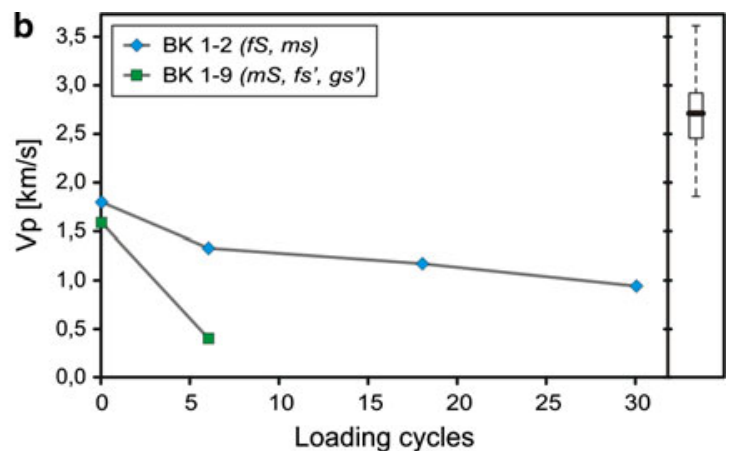

typical range of values based on data from 112 sandstones used as dimension stone (Mosch 2008)

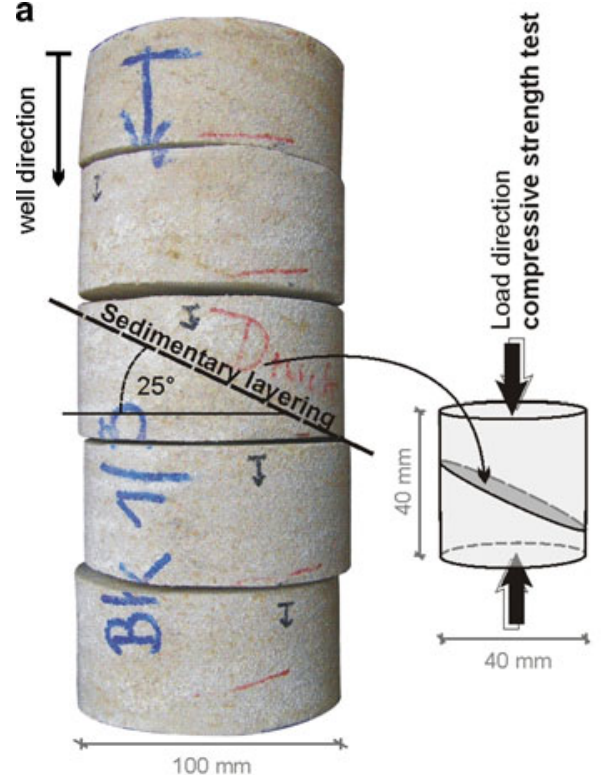

Fig. 14 a Orientation of samples for the compressive strength test. The sedimentary layering dips $25^{\circ}$ to the load direction, reflecting the real situation at depth in the castle hill. b Compressive strength of samples versus effective porosity (ellipsoid confidence region

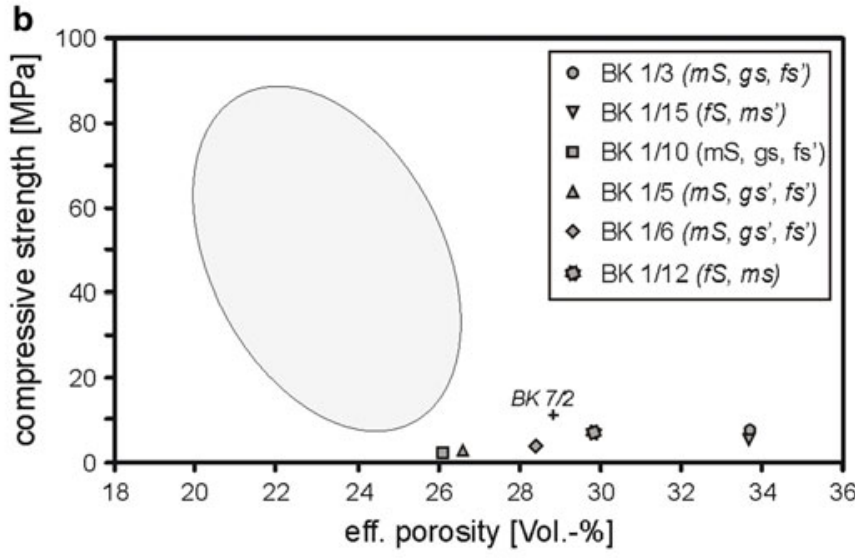

describing $80 \%$ of the expected population based on data for 54 sandstones used as dimension stone with an effective porosity $\geq 20.5$ Vol.\%; Mosch 2008)
Fig. 15 Comparison of compressive strength measured under dry and water-saturated conditions. The boxplot describes the typical range of values based on data for 54 sandstones used as dimension stone (Mosch 2008)

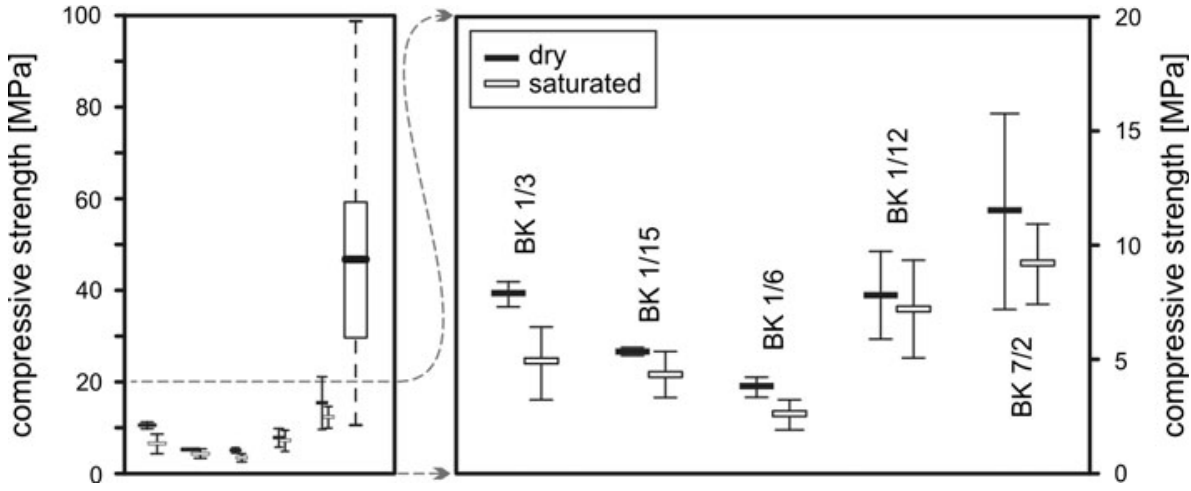

fragments of sandstone were sheared on a naturally existing joint or rupture. The conventional direct shear box used can reach a maximum shear force of $5,000 \mathrm{~N}$ random conditions were simulated with 12 undisturbed dry sandstone samples, 18 undisturbed wet sandstone samples and 34 with pulverised material. For four experiments, 
corresponding to a maximum shear stress of $1,250 \mathrm{kN} / \mathrm{m}^{2}$ $\left(=1.25 \mathrm{MPa}\right.$ on a sample cross section of $\left.40 \mathrm{~cm}^{3}\right)$. The results of the direct shear tests are shown as shear stress diagrams for the samples BK 1-3 (taken at a depth of 4.40-4.70 m, coarse sand, slightly fine sand, medium sand, material of Group B) and the samples BK 1-14 (sampled at a depth of 22.30-22.45 m, fine sand, strong medium sand, material of Group B). Derived shear is depicted as a straight line in Figs. 16b and 17b.

The experimental results document the influence of grain size and wetting conditions. Samples belonging to Group A "Fine sands" under dry conditions have a lower shear stress than samples belonging to Group B "Medium sands". Exceptions are the samples BK 1-4, which have a lower shear stress than sand samples belonging to Group B; and the samples BK 1-14 that have a higher shear stress because of their high percentage of medium sands. Furthermore, the shear experiments showed that sand samples have a lower shear force when they are wet; containing 15 or $20 \%$ of water, than when they are dried. The friction angles that were determined on wet samples are between 66 and $76 \%$ than those determined on the samples under dry conditions.

Focusing on the shear strength of intact samples, additional shear tests on inherent existing sedimentary bedding planes in the sandstone were realised. At least three direct shear tests with constant normal load conditions and one as a so-called dilatancy-free test were performed with a servocontrolled shear test system of MTS $^{\mathrm{TM}}$ with a load capacity of $F_{\text {vertical }} \leq 500 \mathrm{kN}$ and $F_{\text {horizontal }} \leq 250 \mathrm{kN} \quad$ (see Fig. 18a). The original core samples were first sealed against humidity and then encased in concrete in two shear boxes which guarantee a stiff fixation of the sample (Naumann et al. 2008). The samples are tilted and embedded into the boxes to provide shearing along the bedding planes $\left(S_{0}\right)$, where they are exactly positioned for a perpendicular acting normal load $\sigma_{\mathrm{N}}$ (see Fig. 18b). The shear forces act only in the open space between the shear boxes, which is fixed to $20 \mathrm{~mm}$ (Table 1).

The results of the shear test are given in Table 2 and graphically depicted in Fig. 19, where the test curves are shown in stress-displacement and dilatancy-displacement diagrams. The shear stress usually grows in elastic manner up to a peak and then down to a residual value. Peak and residual values are higher with applied normal stress. Due to the surface roughness and asperities, the generated joint tends to dilate upon shear, although this effect tends to level off after a certain amount of prescribed shear displacement, and is lower for higher normal stress.

Figure 19c summarises in a Mohr-Coulomb diagram the test results as maximum shear strength values (red) and residual strength values (pink) derived from multi-step shear tests at various normal loads. No indication of cohesion can be seen, but the peak shear strength values represent the intact rock mass, whereas the residual strength values correspond to the disintegrated sandstone material.

\section{Geotechnical stability analyses}

Geotechnical stability analyses were performed to assess, if the observed subsidence of the church results from deformation of the in situ rock, which may be followed by ground failure due to the vertical load of the buildings. In addition, according to the DIN 10542005 "SubsoilVerification on the safety of earthworks and foundations", the risk of shear failure of the soil beneath the foundation and the general shear slide stability of the rock structure has to be verified. The rock mechanical evaluation is based on the estimated load conditions, the rock mechanical parameters measured in the lab and the actual rock mechanical situation. To check the verification of the limit state serviceability and determine any ultimate bearing
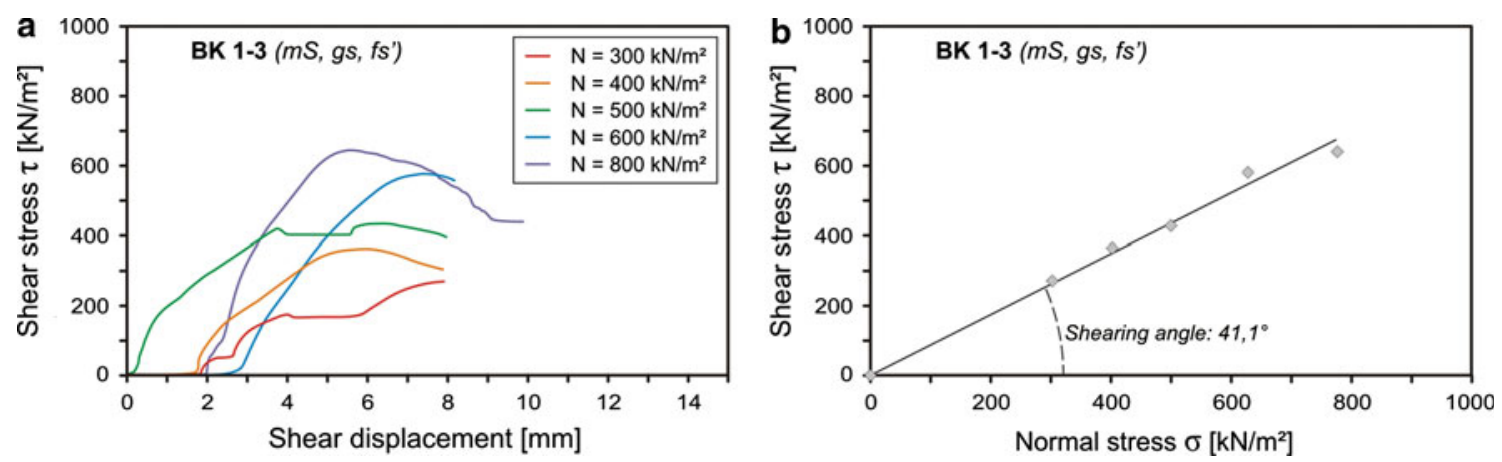

Fig. 16 Shear strength properties of disintegrated sandstone sample (singular) BK 1-3 (medium grained sandstone, partly coarse and fine grained). Left shear stress/displacement diagrams at various normal stresses. Right Mohr-Coulomb diagram 

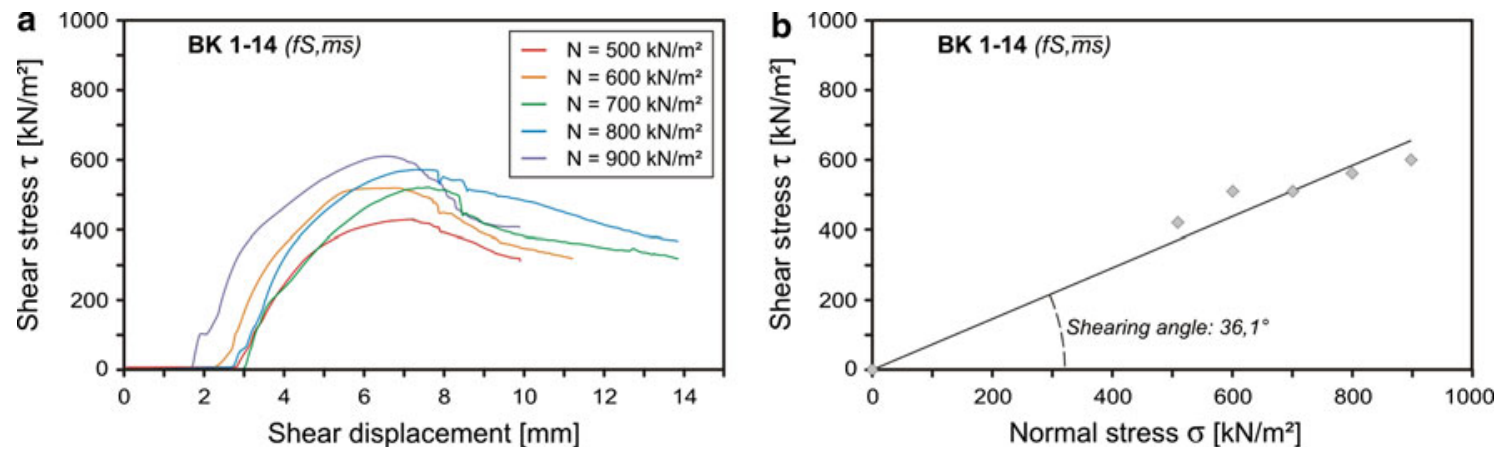

Fig. 17 Shear strength properties of disintegrated sandstone samples (fs, ms): BK 1-14. Left shear stress/displacement diagrams at various normal stresses. Right Mohr-Coulomb diagram

Fig. 18 a MTS shear test system 816 for servo-controlled direct shear tests. b Sketch of the shear boxes with sandstone sample encased in concrete. The sample is rotated to realise shearing along the bedding plane $S_{0}$
Table 1 Results of the shear experiments on disintegrated sandstone samples (note the various grain size fractions)
Table 2 Results of the IfG Leipzig shear tests on samples from drill core BK 1/2007
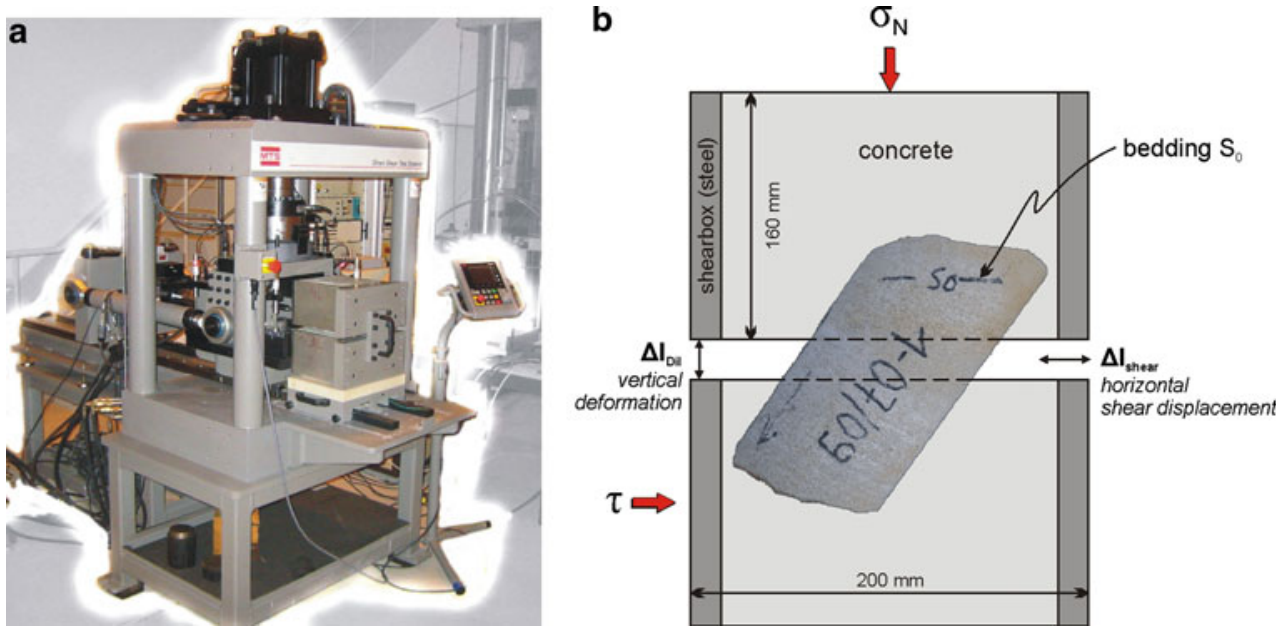

\begin{tabular}{lllcl}
\hline Sample & $\begin{array}{l}\text { Geological } \\
\text { description }\end{array}$ & $\begin{array}{l}\text { Depth } \\
(\mathrm{m} \text { below TGS) }\end{array}$ & $\begin{array}{l}\text { Water } \\
\text { content }(\%)\end{array}$ & $\begin{array}{l}\text { Angle of } \\
\text { friction } \phi\left(^{\circ}\right)\end{array}$ \\
\hline BK 1-4 & ms, gs', fs' & $2.70-3.00$ & 0 & 35.0 \\
& & & 15 & 24.5 \\
BK 1-1 & fs, ms & 3.00 & 20 & 24.9 \\
BK 1-3 & ms, gs, fs ${ }^{\prime}$ & $4.40-4.70$ & 0 & 32.7 \\
BK 1-17 & fs, ms' & 5.70 & 0 & 41.1 \\
& & & 0 & 32.7 \\
BK 1-14 & fs, ms & $22.30-22.45$ & 15 & 23.7 \\
\hline
\end{tabular}

\begin{tabular}{lllll}
\hline Sample & $\begin{array}{l}\text { Geological } \\
\text { description }\end{array}$ & $\begin{array}{l}\text { Depth } \\
(\mathrm{m} \text { below TGS) }\end{array}$ & $\begin{array}{l}\text { Shear } \\
\text { test no. }\end{array}$ & $\begin{array}{l}\text { Angle of } \\
\text { friction } \phi\left({ }^{\circ}\right)\end{array}$ \\
\hline BK 1-5 & ms & 15.0 & $404-S V 1$ & 59 \\
$1-07 / 09$ & fs, ms & $6.85-7.00$ & $404-S V 2$ & 59 \\
$2-07 / 09$ & fs, ms & $7.70-7.85$ & $404-S V 3$ & 59 \\
$3-07 / 09$ & fs, ms & $9.00-9.20$ & $404-S V 4$ & \\
\hline
\end{tabular}



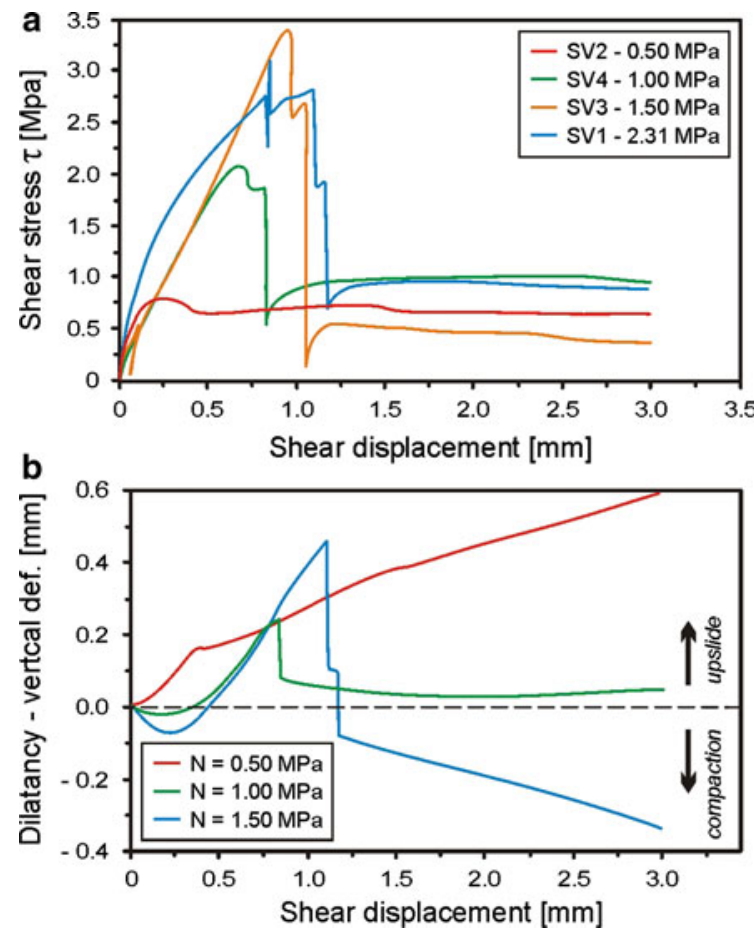

Fig. 19 a Stress-displacement diagram showing four shear tests with varied normal load (0.5-2.31 MPa); note the brittle failure at higher normal loads. b Dilatancy-displacement diagram from three shear tests; at small normal loads the upslide is obvious, while at higher

capacity, the bearing pressures under the church were ascertained in relation to depth.

Estimate of the load situation

An approximate load determination was completed for estimating the weight-related stress situation that the collegiate church has on the subsurface and the resulting stress situation. Therefore, a three-dimensional volume model was made of the building with a CAD system, and the mass and the resulting foundation pressure were determined (Fig. 20; Table 3).

Table 3 shows the church's loads without the foundation. The masses of the underpinning, the counter vault (=counter arches) and St. Nicholas' Church must be added to the south walls' foundation pressure, as well as the buttress by the south tower (Table 4).

\section{Vertical load distribution: probability of a ground failure}

The effective stress below the church consists of the load from the building and the lithostatic load of the underlying sandstone or clay. For the calculations an easily deformable limp strip footing was assumed. A depth dependent stress

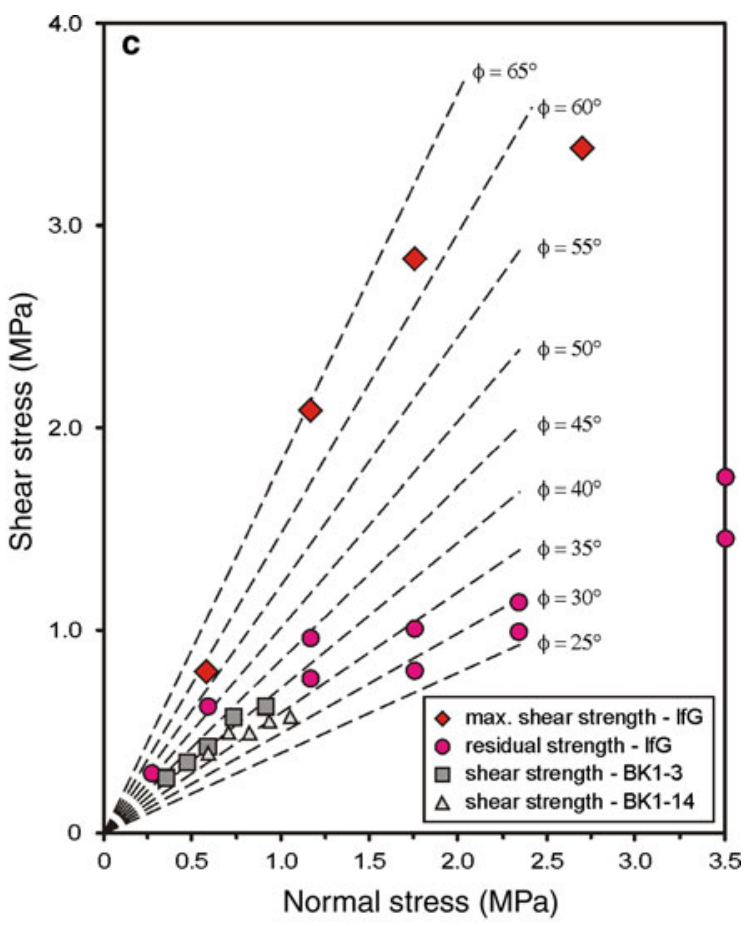

loading conditions compaction occurs as well. $\mathbf{c} \sigma_{\mathrm{n}}-\tau$-diagram comparing IfG shear tests (red rhombi max. shear strength; pink dots residual strength) and HAWK shear tests (grey squares and triangles equal to the IfG's determined residual strength)

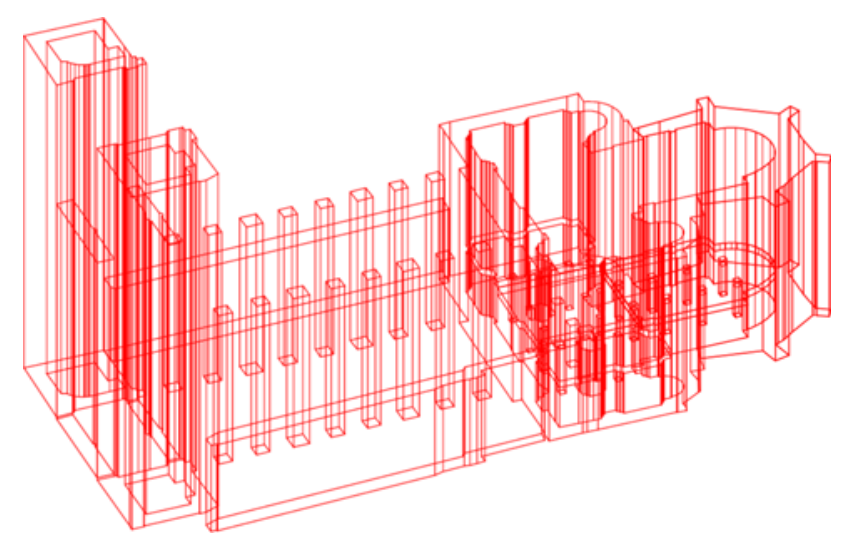

Fig. 20 Schematic 3D model showing the architectural elements (support structure in the St. Servatius church)

of $960 \mathrm{kN} / \mathrm{m}^{2}$ has been determined based on the theory of Steinbrenner (1934) (see Fig. 21). While the building induces vertical stress, which decreases with increasing depth, the lithostatic stress rises linearly with increasing depth. Moreover, the calculated maximum effective stresses directly below the foundation give a value of $960 \mathrm{kN} /$ $\mathrm{m}^{2}$. In spite of the linearly increasing lithostatic pressure, the effective stresses decrease as a result of the church building load, which increases exponentially (see Fig. 21).

The calculations have shown that the effective stress in the underground foundation at the respective depth do not 
Table 3 Load determination to estimate the weight-related stress situation caused by the collegiate church

\begin{tabular}{lllr}
\hline $\begin{array}{l}\text { Architectural } \\
\text { elements }\end{array}$ & $\begin{array}{l}\text { Volumes based on } \\
\text { the 3D-model }\left(\mathrm{m}^{3}\right)\end{array}$ & $\begin{array}{l}\text { Specific gravity } \\
\text { sandstone }\left(\mathrm{kN} / \mathrm{m}^{3}\right)\end{array}$ & Mass $(\mathrm{kN})$ \\
\hline North tower & $1,050.0$ & 20.0 & $21,000.0$ \\
South tower & $1,190.0$ & 20.0 & $23,800.0$ \\
Intermediate nave & 460.0 & 20.0 & $9,200.0$ \\
Nave & $1,030.0$ & 20.0 & $20,600.0$ \\
Transsept & $2,015.0$ & 20.0 & $40,300.0$ \\
Chancel & $1,120.0$ & 20.0 & $22,400.0$ \\
\hline
\end{tabular}

Table 4 Vertical stresses calculated from the identified loads

\begin{tabular}{lllllllllrr}
\hline $\begin{array}{l}\text { Architectural } \\
\text { elements }\end{array}$ & $\begin{array}{l}\text { Volumes based } \\
\text { on the 3D-graphic } \\
\left(\mathrm{m}^{3}\right)\end{array}$ & $\begin{array}{l}\text { Specific gravity } \\
\text { Sandstone } \\
\left(\mathrm{kN} / \mathrm{m}^{3}\right)\end{array}$ & $\begin{array}{l}\text { Load } \\
(\mathrm{kN})\end{array}$ & $\begin{array}{l}\text { Roofage } \\
\left(\mathrm{m}^{2}\right)\end{array}$ & $\begin{array}{l}\text { Distributed load } \\
\text { roof system } \\
\left(\mathrm{kN} / \mathrm{m}^{2}\right)\end{array}$ & $\begin{array}{l}\text { Load } \\
(\mathrm{kN})\end{array}$ & $\begin{array}{l}\text { Total } \\
(\mathrm{kN})\end{array}$ & $\begin{array}{l}\text { Foundation } \\
\text { area }\left(\mathrm{m}^{2}\right)\end{array}$ & $\begin{array}{l}\text { Vertical } \\
\text { stress } \\
\left(\mathrm{kN} / \mathrm{m}^{2}\right)\end{array}$ \\
\hline North tower & $1,050.0$ & 20.0 & $21,000.0$ & 114.0 & 1.0 & 114.0 & $21,114.0$ & 37.9 & 557.1 \\
South tower & $1,190.0$ & 20.0 & $23,800.0$ & 106.0 & 1.0 & 106.0 & $23,906.0$ & 37.9 & 630.8 \\
Intermediate nave & 460.0 & 20.0 & $9,200.0$ & $12,420.0$ & 1.0 & $12,420.0$ & $21,620.0$ & 21.7 & 996.3 \\
Nave & $1,030.0$ & 20.0 & $20,600.0$ & $27,810.0$ & 1.0 & $27,810.0$ & $48,410.0$ & 112.2 & 431.5 \\
Transsept & $2,015.0$ & 20.0 & $40,300.0$ & $54,405.0$ & 1.0 & $54,405.0$ & $94,705.0$ & 132.7 & 713.7 \\
Chancel & $1,120.0$ & 20.0 & $22,400.0$ & $15,120.0$ & 1.0 & $15,120.0$ & $37,520.0$ & 70.8 & 529.9 \\
\hline
\end{tabular}

agree with the compressive strength data obtained by the experiment. In Fig. 21, the depth-dependent compressive strength values supported on wet and dry core samples from bore hole BK 1 are shown together with the depthdependent effective stress. They lie much higher than the maximum effective stresses.

Based on these calculations it can be concluded that the damages of the church building are most probably not due to a softening of the underlying sandstone. The sliding is more likely along the bedding plane, which has a dip of almost $30^{\circ}$. The critical parameter for this movement is the shear strength of the sandstone and the internal angle of friction of which in the wet state is slightly lower than that in the dry state.
Shear failure: the rock mechanical model and basic assumptions

A simplified two-dimensional slope stability model was used for the calculations. These are based on previous investigations where inclined discontinuities (e.g. weakness planes, failure surfaces, etc.) of $<30^{\circ}$ are assumed for the sandstone (see Fig. 22). For the stability analyses a failure model was applied, which uses an idealised rockmass "slides" along the bedding plane. Coulomb shear strengths have been estimated for the failure surface. The actual calculations were made according to the procedure by Janbu (1954), which is suitable for a noncircular failure surface. In this approach, the previous comprehensive
Fig. 21 Idealised vertical tension below the church building

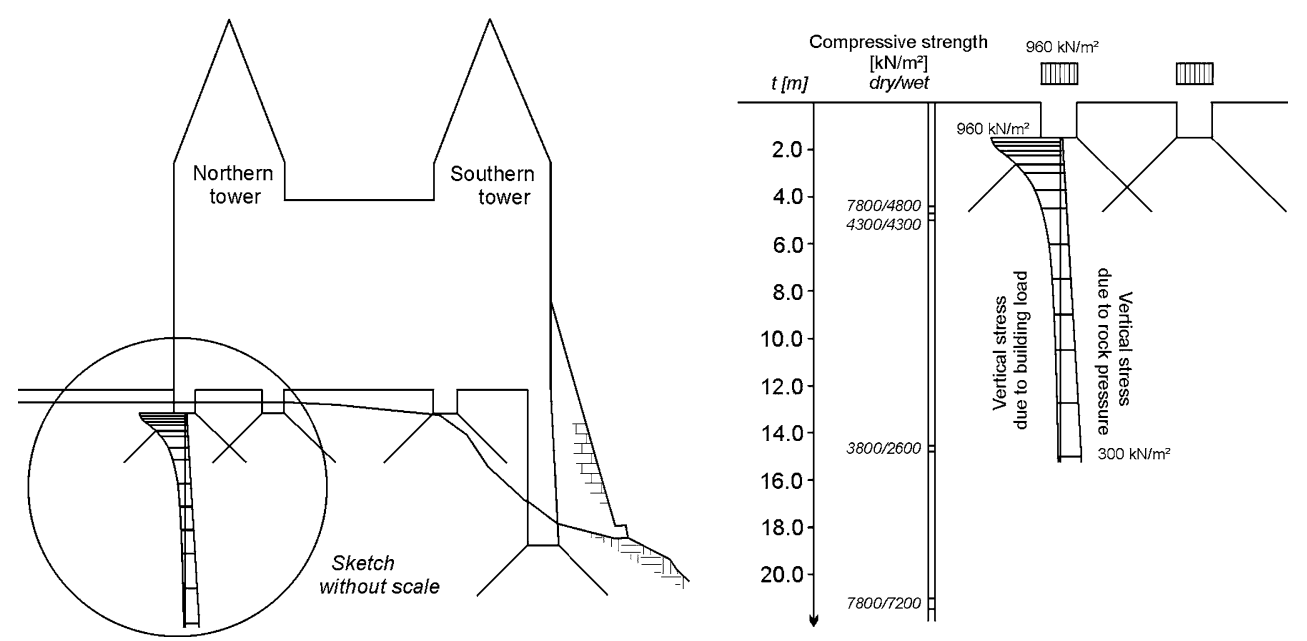


safety concept as well as the current partial safety concept has been considered in separate calculations.

The conventional geotechnical principles are based on limit equilibrium. The factor of safety is the quotient of the sum of the maximum available (characteristic) shear forces that can be developed on the failure surface. This is divided by the sum of the limiting applied (characteristic) shear force required for equilibrium. Therefore, the stability calculation is as follows:

$\eta=\frac{\sum_{i} T_{i}}{L_{h}+\sum_{i} G_{i} \tan v_{i}}$

with

$T_{i}=\frac{c_{i} b_{i}+\left(G_{i}-\left(u_{i}+\Delta u_{i}\right) b_{i}\right) \tan \phi_{i}}{\cos ^{2} v_{i}+(1 / \eta) \tan v_{i} \tan \phi}$

$G_{i}=g_{i}+p_{i} b_{i}$

where $i$ is the number of wedges, $\eta$ is the factor of safety $(-), L_{\mathrm{h}}$ is the horizontal force applied to the wedge $(\mathrm{kN} / \mathrm{m})$, $T_{i}$ is the tangential resistance force of the wedge $i(\mathrm{kN} / \mathrm{m})$, $G_{i}$ is the vertical force applied to the wedge $(\mathrm{kN} / \mathrm{m}), v_{i}$ is the directional change of the wedge $i\left(^{\circ}\right), c_{i}$ is the cohesion shear strength of the wedge $i\left(\mathrm{kN} / \mathrm{m}^{2}\right), \varphi_{i}$ is the angle of internal friction of the wedge $i\left({ }^{\circ}\right), b_{i}$ is the width of the wedge $i(\mathrm{~m}), p_{i}$ is the distributed load on top of the wedge $i\left(\mathrm{kN} / \mathrm{m}^{2}\right), g_{i}$ is the weight of the wedge $i(\mathrm{kN} / \mathrm{m}), u_{i}$ is the pore water pressure in the wedge $i\left(\mathrm{kN} / \mathrm{m}^{2}\right)$, and $\Delta u_{i}$ is the differential pore water pressure in the wedge $i\left(\mathrm{kN} / \mathrm{m}^{2}\right)$.

When the factor of safety is $\eta=1$, the system is situated in the transition from the stable to the unstable state.

In the current partial safety factor concept, the overall stability of the structure is determined by designed values of applied actions and the design value of material properties. It is defined as:

$E_{d} \leq R_{d}$

or with the factor of utilisation

$E_{d} / R_{d} \leq 1$

and $E_{d}=E_{k} \times \gamma_{E}$ as well as $R_{d}=R_{k} / \gamma_{R}$

where $E_{d}$ is the design value of loads parallel to the sliding surface, $E_{k}$ is the characteristic loads parallel to the sliding
Fig. 22 a 2D model with "elevated" lines of sliding; b 2D model with "deep-recumbent" lines of sliding
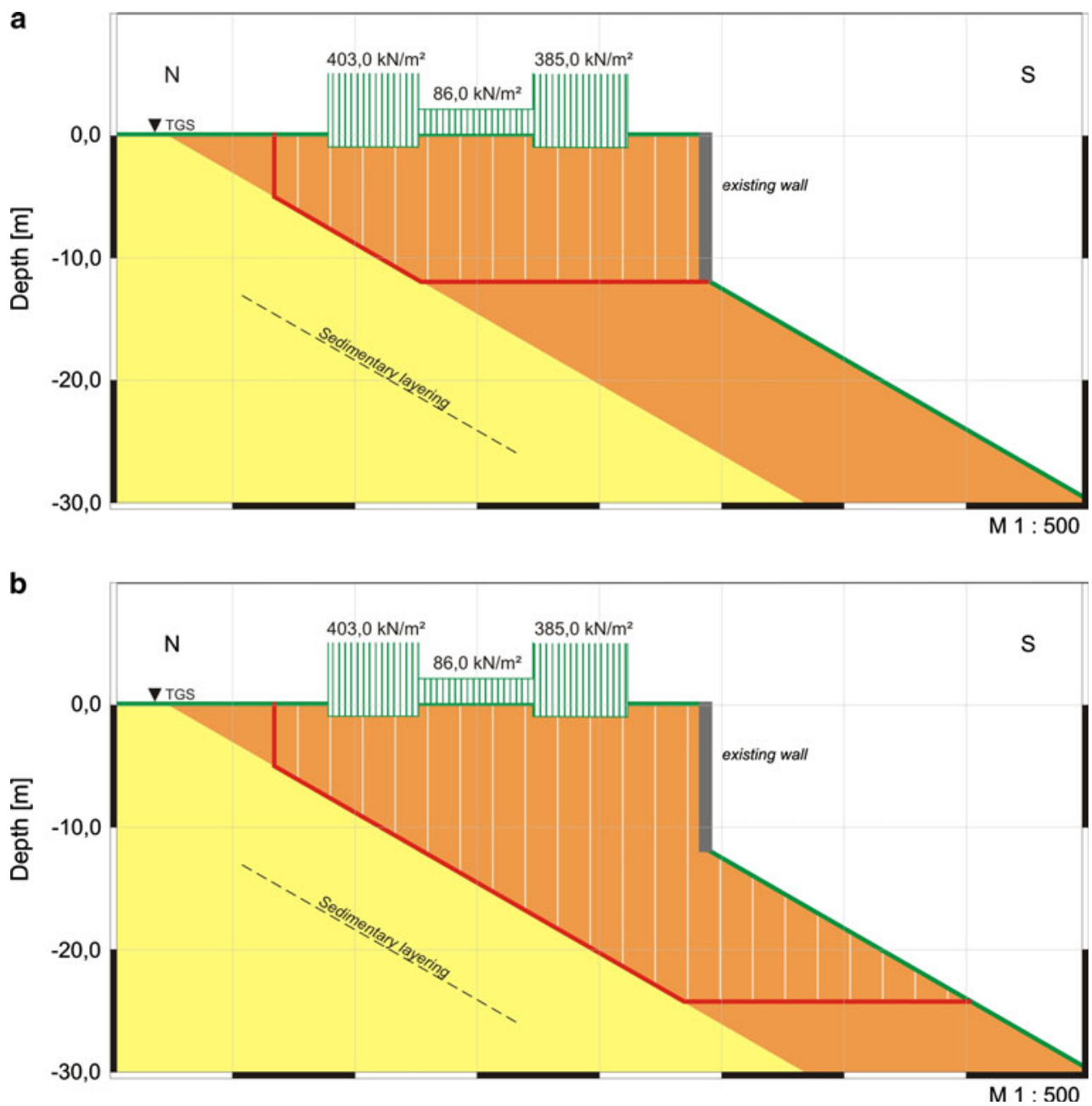
surface, $\gamma_{E}$ is the partial factor of safety for the applied action $(-), R_{d}$ is the design value of material properties parallel to the sliding surface, $R_{k}$ is the characteristic of material properties parallel to the sliding surface, $\gamma_{R}$ is the partial factor of safety for the material properties (-).

The stability is deemed as mathematically proven, if the design value of loads parallel to the sliding plane are smaller or equal to the design value of resistances, i.e. if the factor of utilisation $E_{d} / R_{d}$ is smaller or equal to one (Fig. 22a, b).

Figure 22a, b shows two significant extremes of the position of the sliding surface based on the procedure of Janbu (1954), where the upper failure rockmass slides on the underlying competent rockmass. Different results were obtained from the two geometrical models. In model Fig. 22a, the emergence of the failure surface is directly below the south-east retaining wall, while in model Fig. 22b the failure surface exits further below.

Foundation pressures resulting from the church and used for the calculations based on Janbu are given in Table 4 . The general surface load has been calculated by considering the north and south tower (403.0 and $\left.385 \mathrm{kN} / \mathrm{m}^{2}\right)$ and the remaining building in between $\left(86.0 \mathrm{kN} / \mathrm{m}^{2}\right.$, see Fig. 22a, b).

In the model illustrated in Fig. 22a, a friction angle of $25^{\circ}$, i.e. corresponding to the lowest experimentally measured value was assumed together with a factor of safety $\eta$ of around 2.5. The utilisation factor of the current partial safety is around about 0.5. Therefore, the assumed approach is sufficiently stable enough.

In contrast, the model calculated in Fig. 22b shows an utilisation factor of 1.25 , where the angle of friction is $25^{\circ}$ and the factor of safety $\eta$ is around 1 . The settlements ascertained in the St. Servatius church can be directly traced to the deformation within the geologic structure of the castle hill.

To what extent the first theoretical estimations agree with the actual circumstances will be examined on a more detailed model in the future. For this situation a more comprehensive geological analysis of the sandstone bedding and the intercalated clay layers and their rock mechanical properties are necessary. For the determination of possible sliding planes within the rock mass, the location and orientation has to be verified, e.g. by inclinometer measurements.

\section{Conclusions}

The collegiate church in Quedlinburg exhibits an abundance of structural damages that have been repeatedly repaired over the centuries, especially reconstructions required on the south wall. These include cracks in the masonry at different positions in the building structures, which continue to show strong damages despite the repair work. Peelings or exfoliations on the retaining wall have been known for quite some time. These damages are attributed to weak zones in underlying sandstone bedrock.

The present-day church was established and built predominantly on the foundation of the previous third church. This earlier foundation is made up of gypsum and claybearing materials, which can easily deform by the influence of weathering. Weaknesses in the foundation have been verified on the north side of the collegiate church. The foundation bed lies at about the same level as the upper edge of the castle hill plateau, and is therefore not protected from freeze-thaw weathering. In the underlying foundational sandstone, the upper area shows disintegration to sand at a depth of about $20 \mathrm{~cm}$.

The castle hill consists of monotonous medium- to finegrained sandstones. The early Cretaceous sandstones are intercalated with conglomerate layers and some clay layers, and are only slightly cemented (commonly minor quartzand limonite cement). Drilling encountered an approximately $3-\mathrm{m}$ thick clay layer at a depth of about $16 \mathrm{~m}$. The minor cementation is also responsible for the high porosity, which for the investigated samples show variations of around $30 \%$, but can reach values up to $45 \%$. Stronger cemented areas have a lower porosity due to the limonite cement; however, these have also been affected by secondary dissolution. The porosity and the degree of cementation essentially determine the rock mechanical properties.

All tested samples show very low compressive strength but can reach values up to $35 \%$ when compared with the usual observed values form sandstones. The highest values cover a range up to $8 \mathrm{MPa}$, while under the influence of moisture these values are significantly reduced up to $40 \%$. The deterioration of the sandstones with respect to the loss of cohesion is a widely observed phenomenon. Hydric properties as well as the very poor resistance to frost weathering may explain that the upper part of the sandstone has weathered to sand. An increased softening of the sandstone bedrock by the influence of greater amounts of moisture can be excluded.

The first results from the technical laboratory experiments consist of characteristic soil- and rock-mechanical values. Their validity is yet to be confirmed by ongoing mechanical tests in combination with rock-mechanical modelling. However, the initial results can be looked upon as representative for the structure of the entire castle hill. Furthermore, the evaluations showed that the stresses resulting from the collegiate church are a lot smaller than the breaking strengths of the solid foundation.

The reasons for the damages in the collegiate church are still unclear. Foundation problems resulting from construction deficiencies due to its complex building history, 
which has led to higher loads or the redistribution of loads from the inclusion of subsequent building elements, must be considered as a (very) possible cause. Based on the present state of knowledge, it can be assumed that the sandstone does form a suitable load-bearing foundation for the collegiate church, even though it has a low strength. In spite of the comparatively low and demonstrated strengths for sandstones, an estimation of the superimposed load by the building documents that a failure of the underground in the sense of a base or matrix failure, are overall to high when using uniaxial compressive strengths. The existing crack formations in the church are only a few millimetres in size and oriented parallel to the long axis. These are clearly not due to a collapse of the substratum (base failure). Moreover, the probability that a landslide of the hill parallel to the southward dipping bedding planes (shear failure along weak zones) will occur, seems unlikely according to the results from geotechnical modelling, even under the presupposition of the more unfavourable case (a friction angle of around $25^{\circ}$ and no cohesion). Direct shear experiments with an approximate $60^{\circ}$ angle of friction on intact material clearly demonstrate the safety margins. More extensive damage would be expected by a landslide type of movement, which in consideration of the long life of the buildings on the castle hill would surely have caused a collapse of the church. Furthermore, previous investigations consisting of drilling, geologic mapping and seismic tomography have not located any potential slip planes (e.g. interbedded clay horizons) in the near-surface sandstone in close proximity to the castle hill buildings. However, a prominent clay horizon does occur about 16-m below the buildings. Further clinometer measurements will show to what extent movement takes place in the sandstone blocks due to the presence of a deeper claystone layer. Preliminary mapping reveals that the claystone layer is about 3-m thick, and occurs throughout the entire castle hill with a dip of ca. $25^{\circ}-30^{\circ}$ to the $\mathrm{SW}$ and parallel to the sandstone bedding. This bed occurs at a depth of about 16-m below the top edge of the plateau surface.

This leads to the assumption that another form of failure is the cause of the settling in the church building. The stability calculations that were made on notional failure blocks showed that the system's deformation behaviour can be simulated with the help of these kinds of models. The calculative model of failure should be refined by doing other evaluations. Therefore, more local surveying, soil- as well as rock-mechanical tests and modelling approaches will be necessary.

Open Access This article is distributed under the terms of the Creative Commons Attribution Noncommercial License which permits any noncommercial use, distribution, and reproduction in any medium, provided the original author(s) and source are credited.

\section{References}

Auberg R, Palecki S, Setzer MJ (1999) Zerstörungsfreie Prüfung der inneren Schädigung von Beton durch Frostangriff. - DGZfP, Fachtagung Bauwerksdiagnose - Praktische Anwendungen Zerstörungsfreier Prüfungen, München

Boggs S Jr, Kwon Y-I, Goles GG, Rusk BG, Krinsley D, Seyedolali A (2002) Is quartz cathodoluminescence color a reliable provenance tool? A quantitative examination. J Sed Res 72(3):408415

DIN 1054 (2005) Baugrund - Sicherheitsnachweise im Erd- und Grundbau. Beuth-Verlag, Berlin

DIN 18123 (1996) Baugrund, Untersuchung von Bodenproben Bestimmung der Korngrößenverteilung. Beuth-Verlag, Berlin

Heckner J, Rappsilber I, Strobel G, Lindner U, Schicht T (2005) Seismische Tomographie des Quedlinburger Schlossbergs. - Mitt. Geologie und Bergwesen Sachsen-Anhalt 8:101-107; Halle/S

Janbu N (1954) Application of composite slip surfaces for stability analysis. In: Proceedings of European conference on stability earth slopes, vol 3, Stockholm

Morales Demarco M, Jahns E, Rüdrich J, Oyhantcabal P, Siegesmund $S$ (2007) The impact of partial water saturation in rock strength: an experimental study on sandstone. Z dt Ges Geowiss 158/ 4:869-882

Mosch S (2008) Optimierung der Exploration, Gewinnung und Materialcharakterisierung von Naturwerksteinen. - Dissertation. University of Göttingen, $275 \mathrm{p}$

Naumann D, Popp T, Minkley W (2008) Labortechnische Ermittlung von Scherfestigkeitsparametern an Trennflächen mittels MTSSchertestsystem des IfG Leipzig - Methodik und Beispiele. In: Gattermann J, Bruns B (eds) Fachseminar - Messen in der Geotechnik 2008. 23-24 Oktober 2008 Braunschweig. Mitteilung des Instituts für Grundbau und Bodenmechanik - Technische Universität Braunschweig. Heft Nr. 87, pp 127-144

Peter A (2005) Schlossberg Quedlinburg - Baugrundmodell auf Grundlage geophysikalischer und geotechnischer Untersuchungen. Unpublished Report, 36 p, with Appendixes, Quedlinburg

Prescher H (1955) Geologische Untersuchungen in der Stiftskirche zu Quedlinburg. Unpublished Report, 21 p. Freiberg/Sa

Ruedrich J, Siegesmund S (2006) Salt and ice crystallization in porous sandstones. In: Siegesmund S, Steiger M (Hrsg) Salt decay. Environ Geol 52(2):225-249

Steinbrenner W (1934) Tafeln zur Setzungsberechnung, vol 1. Die Straße, Heft

Tröger K (1955) Bericht über die Ergebnisse der im Jahre 1955 durchgeführten geologischen Untersuchungen im Gebiet des Schlossberges Quedlinburg. Unpublished Report, Freiberg/Sa, $49 \mathrm{p}$

Voigt Th, von Eynatten H (2008) Field trip POST2-syntectonic sedimentation in front of a late Cretaceous growth fault-the Harz Mountains and the adjacent Subhercynian Basin (Germany). In: 26th IAS regional meeting held jointly with the SEPM-CES SEDIMENT meeting 2008, Bochum, Germany, September 1-3, 2008. Excursion Guidebook, vol 237. Exkurs.f. und Veröffentl. DGG, pp 59-94, Hannover

Voigt Th, von Eynatten H, Franzke H-J (2004) Late Cretaceous unconformities in the Subhercynian Cretaceous Basin (Germany). Acta Geol Pol 54/4:673-694

Voigt Th, Wiese F, von Eynatten H, Franzke H-J, Gaupp R (2006) Facies evolution of syntectonic Upper Cretaceaous deposits in the Subhercynian Cretaceaous Basin and adjouning areas (Germany). Z dt Ges Geowiss 157/2:203-244 Stuttgart

Voigtländer K (1989) Die Stiftskirche St. Servatii zu Quedlinburg. Geschichte ihrer Restaurierung und Ausstattung. Berlin (ISBN 3-05-000580-7) 
von Eynatten H, Voigt Th, Meier A, Franzke HJ, Gaupp R (2008) Provenance of Cretaceous clastics in the Subhercynian Basin: constraints to exhumation of the Harz Mountains and timing of inversion tectonics in Central Europe. Int J Earth Sci (Geol Rundsch) 97:1315-1330
Wäscher H (1959) Der Burgberg in Quedlinburg. Geschichte seiner Bauten bis zum ausgehenden 12. Jahrhundert nach den Ergebnissen der Grabungen von 1938 bis 1942. Deutsche Bauakademie, Schriften des Instituts für Theorie und Geschichte der Baukunst. Henschel-Verlag, Berlin, 100 p 